OPEN ACCESS

Edited by:

Atsushi Asakura

University of Minnesota Twin Cities,

United States

Reviewed by:

Akiyoshi Uezumi,

Tokyo Metropolitan Institute of

Gerontology, Japan

So-ichiro Fukada,

Osaka University, Japan

*Correspondence:

Masatoshi Suzuk

masatoshi.suzuki@wisc.edu

Specialty section:

This article was submitted to

Stem Cell Research,

a section of the journal

Frontiers in Cell and Developmental

Biology

Received: 28 June 2019 Accepted: 01 November 2019 Published: 26 November 2019

Citation:

Tey S-R, Robertson S, Lynch E and Suzuki M (2019) Coding Cell Identity of Human Skeletal Muscle Progenitor

Cells Using Cell Surface Markers:

Current Status and Remaining

Challenges for Characterization and Isolation. Front. Cell Dev. Biol. 7:284.

doi: 10.3389/fcell.2019.00284

\section{Coding Cell Identity of Human Skeletal Muscle Progenitor Cells Using Cell Surface Markers: Current Status and Remaining Challenges for Characterization and Isolation}

\author{
Sin-Ruow Tey ${ }^{1}$, Samantha Robertson ${ }^{1}$, Eileen Lynch $^{1}$ and Masatoshi Suzuki ${ }^{1,2 *}$ \\ ${ }^{1}$ Department of Comparative Biosciences, University of Wisconsin, Madison, WI, United States, ${ }^{2}$ The Stem Cell and \\ Regenerative Medicine Center, University of Wisconsin, Madison, WI, United States
}

Skeletal muscle progenitor cells (SMPCs), also called myogenic progenitors, have been studied extensively in recent years because of their promising therapeutic potential to preserve and recover skeletal muscle mass and function in patients with cachexia, sarcopenia, and neuromuscular diseases. SMPCs can be utilized to investigate the mechanisms of natural and pathological myogenesis via in vitro modeling and in vivo experimentation. While various types of SMPCs are currently available from several sources, human pluripotent stem cells (PSCs) offer an efficient and cost-effective method to derive SMPCs. As human PSC-derived cells often display varying heterogeneity in cell types, cell enrichment using cell surface markers remains a critical step in current procedures to establish a pure population of SMPCs. Here we summarize the cell surface markers currently being used to detect human SMPCs, describing their potential application for characterizing, identifying and isolating human PSC-derived SMPCs. To date, several positive and negative markers have been used to enrich human SMPCs from differentiated PSCs by cell sorting. A careful analysis of current findings can broaden our understanding and reveal potential uses for these surface markers with SMPCs.

Keywords: skeletal muscle, skeletal muscle progenitor cells, cell surface markers, human pluripotent stem cells, human induced pluripotent stem cells, muscular dystrophy, neuromuscular diseases

\section{INTRODUCTION}

The most pronounced symptom of neuromuscular disorders is loss of skeletal muscle mass and strength, which causes functional decline and loss of independence in patients (Morrison, 2016; Mary et al., 2018). However, muscular deterioration is not always indicative of disease. Age-related progressive muscle atrophy and reduction of muscle function in healthy older adults is known as sarcopenia (Santilli et al., 2014; Ogawa et al., 2016; Marzetti et al., 2017). Although both a decrease in myocyte number (hypoplasia) and size (atrophy) are consistently observed in sarcopenic skeletal muscle (Deschenes, 2004; Narici and Maffulli, 2010), the precise biological mechanisms driving the precipitous decline in muscle mass and function are not well-understood. Current treatment options for these muscle conditions are only palliative, and to date there is no effective cure for any type of muscle wasting. 
Stem cells offer the potential to become a realistic means to suppress the aging process in humans. To treat muscle wasting, stem cell-based therapy is the most attractive approach, as demonstrated in numerous pre-clinical studies and several clinical trials (Wilschut et al., 2012; Bajek et al., 2015; Ryder et al., 2017; Tompkins et al., 2017). For full muscle repair and regeneration, the formation of contractile muscle units is required. The obvious candidates for cell therapy are skeletal muscle progenitor cells (SMPCs, also known as myogenic progenitors). These cells can differentiate into skeletal myocytes with high efficiency and terminally achieve the formation of contractile muscle units, which is required for muscle repair and regeneration in the implanted muscle. There is a range of available cell sources to propagate SMPCs in culture, including from fetal muscle, adult muscle, and nonmuscle somatic tissues. Furthermore, recent advances in stem cell technology allow us to use human pluripotent stem cells (PSCs) as a virtually indefinite new cell source for SMPC preparation. Human PSCs, which include embryonic stem cells (ESCs) and induced pluripotent stem cells (iPSCs), can overcome problems associated with expansion to large cell numbers for clinical use. Therefore, human PSC-derived SMPCs hold great promise for cell-based therapy to achieve muscle regeneration.

Not limited for use in cell-based regenerative therapy, human PSC-derived SMPCs are also available for in vitro modeling to study normal and pathological mechanisms in human skeletal muscle. As there is a large void between pre-clinical work carried out in rodent models and translating these therapies to humans, utilizing human PSC-derived SMPCs to study muscle wasting would help bridge the gap in knowledge. While in vitro culture systems have limitations and cannot completely recapitulate the complex in vivo milieu, they have powerful experimental advantages that enable us to study inaccessible human cell types in a controlled setting. Through in vitro drug screening using human PSC-derived SMPCs, we can possibly identify new mechanisms and molecules that have the capacity to prevent muscle wasting and atrophy during normal aging or disease processes.

This review catalogs the current findings on cell surface markers to identify human SMPCs. Here we focus on surface markers that have been reported in human PSC-derived SMPCs and compare their expression in other systems. Specific cell markers and/or cell surface proteins can be used for isolation, identification, and characterization of viable SMPCs. A better understanding of how SMPC markers are regulated in vitro and in vivo can help resolve enduring questions and challenges such as (1) the origins of SMPCs; (2) signaling mechanisms that drive lineage progression; (3) optimal isolation techniques; (4) selective enrichment of populations with clinical relevance, either for in vitro modeling and/or ex vivo therapy; and (5) potential genetic manipulations and/or pharmaceutical interventions to correct deteriorating muscle phenotypes. Similarities or differences in SMPC surface marker expression might be indicative of their stemness, myogenic differentiation propensity, and lineage potential to assume non-myogenic fates.

\section{SKELETAL MUSCLE DEVELOPMENT AND SMPCS}

There are various types of progenitor cells that have the ability to differentiate into skeletal myocytes. These cells include muscle satellite cells, muscle-derived stem cells (MDSCs), side population (SP) cells, mesoangioblasts and pericytes (reviewed in Hosoyama et al., 2014). Different sources have been used to propagate SMPCs in culture, including fetal muscle, adult muscle, non-muscle somatic tissues, and pluripotent stem cells (PSCs).

Skeletal muscle satellite cells are a type of adult SMPC localized beneath the basal lamina of adult muscle fibers. Regeneration of postnatal and adult muscles relies on satellite cells (Mauro, 1961; Starkey et al., 2011; Pallafacchina et al., 2013; $\mathrm{Xu}$ et al., 2015). These cells are mitotically quiescent in adult muscles. When the muscle is stimulated by stress or trauma, satellite cells are activated to divide, giving rise to daughter satellite cells to replenish the quiescent satellite cell pool and/or to undergo terminal differentiation for muscle repair (Bischoff and Heintz, 1994; Morgan and Partridge, 2003; Kuang et al., 2007; Le Grand et al., 2009; Xu et al., 2015). Both quiescent and activated satellite cells express Pax7 (Seale et al., 2000), whereas Myf5 is only expressed in activated satellite cells (Crist et al., 2012; $\mathrm{Xu}$ et al., 2015). With the expression of a muscle determinant factor MyoD, satellite cells are committed to become myoblasts, or myogenic precursor cells, which then terminally differentiate into multinucleated myotubes (Tapscott et al., 1988; Bischoff and Heintz, 1994; Seale et al., 2000; Morgan and Partridge, 2003; Kuang et al., 2007; Le Grand et al., 2009; Crist et al., 2012).

Muscle-derived stem cells (MDSCs) can be isolated from adult muscle biopsies by a combination of enzyme digestion and serial plating to collagen-coated culture plates, as these cells are less adhesive compared to other cell types in skeletal muscle (Vella et al., 2011). MDSCs are biologically, biochemically and genetically distinct from satellite cells (Qu-Petersen et al., 2002; Alessandri et al., 2004; Deasy et al., 2005; Usas et al., 2011). Human MDSCs are positive for CD105, CD133, vimentin and desmin, but negative for CD31, CD34, CD45, FLK-1/KDR, von Willebrand factor, VE-cadherins, and BCL2 (Alessandri et al., 2004). On the other hand, murine MDSCs have been known to express Sca-1 and CD34 (Cao et al., 2003; Deasy et al., 2005). Human MDSCs induced for myogenic differentiation in culture express striated-muscle actin, smooth-muscle actin, and desmin (Alessandri et al., 2004). Intramuscular transplant of human MDSCs was able to reverse muscle atrophy and promote phrenic nerve regeneration in pre-injured and immunocompetent alphasarcoglycan null mice (Lavasani et al., 2014). MDSCs can self-renew and differentiate into various cell types including non-muscle cells such as astrocytes, neurons, osteoblasts, chondrocytes, adipocytes, and cardiomyocytes (Deasy et al., 2001; Alessandri et al., 2004; Usas et al., 2011; Tchao et al., 2013). As demonstrated in a mouse model of acute hindlimb injury, multipotent MDSCs can be especially useful when muscle degeneration affects the myotendinous junction and the muscleassociated tendon. This is because MDSCs can potentially 
differentiate into fibroblasts or tenocytes to reconstitute the wasted muscle-tendon units (Hashimoto et al., 2016).

Side population (SP) cells are named after their ability to efflux the DNA-binding dye Hoechst 33342 and form a side population on Fluorescence Activated Cell Sorting (FACS) analysis (Goodell et al., 1996). This cell type was first identified in murine bone marrow as a subset of hematopoietic stem cells (HSCs; Goodell et al., 1996). Murine bone marrow SP cells were found to participate in muscle regeneration (Gussoni et al., 1999). Later, an isolation protocol was developed to enrich for murine skeletal muscle SP cells (Gussoni et al., 1999). These murine skeletal muscle SP cells were also able to replenish the satellite cell pool, which can contribute to muscle regeneration following systemic delivery (Gussoni et al., 1999; Asakura et al., 2002; Bachrach et al., 2006). While significant information is available for murine SP cells, studies in human skeletal muscle SP cells are relatively limited due to their scarcity, heterogeneity and difficulty to expand in vitro. It has been shown that human fetal muscle SP cells, which express CD146, Myf5, and Pax7, are highly myogenic and expandable in vitro but retain limited engraftment potential in vivo (Lapan et al., 2012).

Mesoangioblasts and pericytes are adult progenitor cells associated with vasculature running through the muscle tissue with a significant capacity to regenerate skeletal muscle. Mesoangioblasts are a type of mesodermal stem cell located in the walls of the embryonic aorta and the vessels of postnatal tissues (Tonlorenzi et al., 2007). As mesoangioblasts possess strong myogenic potential, systemic delivery of these cells into the blood stream enables them to reach and integrate into the target site of pathological muscles (Sampaolesi et al., 2003; Cossu et al., 2015). Intramuscular transplantation of muscle-derived CD133 ${ }^{+}$ mesoangioblasts into a mouse cryoinjury model re-populated the satellite cell niche and was able to activate a regenerative response after subsequent re-injury (Meng et al., 2014). Interestingly, mesoangioblasts are known to express angiogenic cell markers such as CD34, Sca-1, and Fetal Liver Kinase 1 (De Angelis et al., 1999). Pericytes are embedded within the basement membrane of micro-vasculatures in adult skeletal muscles (Armulik et al., 2011; Cappellari and Cossu, 2013). These cells express Myf5 and Tissue-Nonspecific Alkaline Phosphatase (Dellavalle et al., 2007; Cappellari and Cossu, 2013).

A number of recent studies acknowledge that human PSCs, which include ESCs and iPSCs, can serve as a promising source for SMPC preparation. PSCs have the potential to differentiate into any cell lineage (Thomson, 1998; Takahashi et al., 2007). As iPSCs can be prepared using the somatic cells of a patient, they are a powerful tool for disease modeling, gene correction and drug screening in culture, and are a robust cell source for immuno-privileged clinical applications. In the last decade, SMPCs have been derived from PSCs via either transgenebased methods (i.e., overexpression of myogenic genes) or transgene-free approaches (i.e., supplementation of myogenic growth factors and/or signaling molecules in defined culture) (reviewed in Jiwlawat et al., 2018). Most protocols aim to generate satellite cell-like populations because satellite cells are considered bona fide skeletal muscle stem cells with both stem-like properties and myogenic activities. When deriving
SMPCs from PSCs, especially via transgene-free approaches, the resulting cell populations commonly display high heterogeneity. Therefore, characterization and purification of PSC-derived SMPCs is crucial to promote culture expansion efficiency and increase engraftment rate following transplantation (Kim et al., 2017). Currently available methods for SMPC isolation often require fixation and intracellular staining, which prevents further examination of behavior and functionality after sorting. To preserve the viability of enriched transgene-free SMPCs, isolation should be based exclusively on unique surface markers that do not disrupt or compromise the integrity of the cells. Moreover, profiling by cell surface markers would also be valuable to identify how PSC-derived SMPCs resemble SMPC types such as mesoangioblasts, SP cells, and satellite cells.

\section{CELL SURFACE MARKERS TO DEFINE HUMAN PSC-DERIVED SMPCS}

Different molecular signatures are displayed in the SMPCs derived from various cell sources. Therefore, a profile of cell surface proteins can be used to define a specific cell type. A cell isolation procedure can use either positive selection or negative selection. Positive selection isolates the target cell type from the entire population, whereas negative selection depletes all other cell types of the population with only the target cells remaining. A combined use of different surface markers has worked successfully to enrich human PSC-derived SMPCs and deplete undesirable cell types by cell sorting. Although these individual works support the feasibility of SMPC sorting using multiple markers, such complicated procedures would critically dampen enthusiasm for potential therapeutic applications of PSC-derived SMPCs. In this section, we will introduce cell surface markers that can positively or negatively identify SMPCs derived from human ESCs and iPSCs (Table 1); however, this is not an exhaustive list. We will also summarize the expression of these markers on SMPCs from the other tissue sources. For consistency, SMPCs in this review are defined by: (1) ability to self-renew prior to differentiation induction and upon differentiation induction; (2) ability to form myofibers; and (3) expression of at least one protein marker that has been commonly seen in skeletal muscle progenitors, myoblasts, and myocytes. All cells and tissues mentioned onwards are sourced from humans, unless specified otherwise.

\section{Positive Surface Markers for Human SMPCs CD10}

CD10 is commonly recognized as a cancer marker but is also used to identify specific populations of SMPCs (Maguer-Satta et al., 2011). This marker represents a type of endopeptidase protein also known as neprilysin, membrane metallo-endopeptidase, neutral endopeptidase, or common acute lymphoblastic leukemia antigen (Maguer-Satta et al., 2011). CD10 is also involved in hematopoiesis and B cell-innate immunology (Maguer-Satta et al., 2011). In a recent study using transgene-free PSCs and Pax7/Myf5 reporter ESCs, CD10 ${ }^{+} / \mathrm{CD} 24^{-}$cells represented 
TABLE 1 | Common markers to identify SMPCs from human PSCs and muscles.

\begin{tabular}{|c|c|c|c|c|c|c|c|c|c|c|}
\hline & & \multicolumn{4}{|c|}{ PSCs } & \multicolumn{2}{|r|}{ Adult muscle } & \multicolumn{2}{|r|}{ Fetal muscle } & \multirow{3}{*}{$\begin{array}{l}\text { Other sources } \\
\text { (see NOTE) }\end{array}$} \\
\hline & & \multicolumn{2}{|r|}{ iPSCs } & \multicolumn{2}{|r|}{ ESCs } & \multirow[b]{2}{*}{ Presence } & \multirow[b]{2}{*}{ References } & \multirow[b]{2}{*}{ Presence } & \multirow[b]{2}{*}{ References } & \\
\hline & & Presence & References & Presence & References & & & & & \\
\hline \multirow[t]{9}{*}{$\begin{array}{l}\text { Positive } \\
\text { markers }\end{array}$} & CD10 & + & Wu et al., 2018 & + & Wu et al., 2018 & + & $\begin{array}{l}\text { Crisan et al., 2008; Lecourt } \\
\text { et al., 2010; Wu et al., } 2018\end{array}$ & + & Crisan et al., 2008 & \\
\hline & CD13 & + & $\begin{array}{l}\text { Darabi et al., 2012; Tedesco } \\
\text { et al., } 2012\end{array}$ & + & Darabi et al., 2012 & + & $\begin{array}{l}\text { Morosetti et al., 2006; } \\
\text { Dellavalle et al., 2007; Crisan } \\
\text { et al., 2008; Lecourt et al., } \\
\text { 2010; Pisani et al., 2010b }\end{array}$ & + & $\begin{array}{l}\text { Crisan et al., 2008; } \\
\text { Castiglioni et al., } 2014\end{array}$ & \\
\hline & CD29 & + & $\begin{array}{l}\text { Awaya et al., 2012; Darabi } \\
\text { et al., 2012; Abujarour et al., } \\
\text { 2014; Magli et al., 2017; } \\
\text { Sakai-Takemura et al., } 2018\end{array}$ & + & $\begin{array}{l}\text { Awaya et al., 2012; Darabi } \\
\text { et al., 2012; Magli et al., } \\
2017\end{array}$ & + & $\begin{array}{l}\text { Lecourt et al., 2010; Woodard } \\
\text { et al., 2014; Charville et al., } \\
\text { 2015; Xu et al., 2015; Garcia } \\
\text { et al., 2018*; Lorant et al., } \\
2018\end{array}$ & + & Castiglioni et al., 2014 & \\
\hline & CD44 & + & $\begin{array}{l}\text { Darabi et al., 2012; Tedesco } \\
\text { et al., 2012; Abujarour et al., } \\
2014\end{array}$ & + & Darabi et al., 2012 & + & $\begin{array}{l}\text { Morosetti et al., 2006; } \\
\text { Dellavalle et al., 2007; Lecourt } \\
\text { et al., 2010; Pisani et al., } \\
\text { 2010b; Lorant et al., } 2018\end{array}$ & + & $\begin{array}{l}\text { Crisan et al., 2008; } \\
\text { Castiglioni et al., } 2014\end{array}$ & \\
\hline & CD54 & + & Magli et al., 2017 & + & Magli et al., 2017 & & & & & \\
\hline & CD56 & $+/-$ & $\begin{array}{l}\text { (+): Awaya et al., 2012; } \\
\text { Darabi et al., 2012; Abujarour } \\
\text { et al., 2014; Choi et al., } \\
\text { 2016; Uezumi et al., 2016; } \\
\text { Hicks et al., 2017; } \\
\text { Sakai-Takemura et al., } 2018 \\
\text { (-): Darabi et al., 2012; } \\
\text { Awaya et al., 2012; } \\
\text { Tedesco et al., 2012; Uezumi } \\
\text { et al., 2016; Sakai-Takemura } \\
\text { et al., } 2018\end{array}$ & +/low & $\begin{array}{l}\text { (+): Barberi et al., 2007; } \\
\text { Awaya et al., 2012; Darabi } \\
\text { et al., 2012; Albini et al., } \\
\text { 2013; Hwang et al., 2014, } \\
\text { Goudenege et al., 2012; } \\
\text { Hicks et al., 2017; Rao et al., } \\
2018 \\
\text { (low): Caron et al., } 2016\end{array}$ & $+/-$ & $\begin{array}{l}\text { (+): Sinanan et al., 2004; } \\
\text { Dellavalle et al., 2007; Zheng } \\
\text { et al., 2007; Crisan et al., } \\
\text { 2008; Lindström and Thornell, } \\
\text { 2009; Negroni et al., 2009; } \\
\text { Lecourt et al., 2010; Pisani } \\
\text { et al., 2010a; Okada et al., } \\
\text { 2012; Zheng et al., 2012; } \\
\text { Agley et al., 2013; Bareja } \\
\text { et al., 2014; Marg et al., 2014; } \\
\text { Woodard et al., 2014; Xu } \\
\text { et al., 2015; Alexander et al., } \\
\text { 2016; Franzin et al., 2016; } \\
\text { Uezumi et al., 2016; Garcia } \\
\text { et al., 2018*; Lorant et al., } \\
\text { 2018 (-): Proksch et al., } 2009\end{array}$ & + & $\begin{array}{l}\text { Castiglioni et al., 2014; Hicks } \\
\text { et al., } 2017\end{array}$ & $\begin{array}{l}\text { Placenta } \\
\text { (Park et al., } \\
\text { 2011) }\end{array}$ \\
\hline & CD63 & + & Darabi et al., 2012 & + & Darabi et al., 2012 & + & Dellavalle et al., 2007 & & & \\
\hline & CD73 & + & Awaya et al., 2012 & + & $\begin{array}{l}\text { Barberi et al., 2005, 2007; } \\
\text { Awaya et al., 2012; } \\
\text { Goudenege et al., } 2012\end{array}$ & + & $\begin{array}{l}\text { Crisan et al., 2008; Lecourt } \\
\text { et al., 2010; Woodard et al., } \\
\text { 2014; Uezumi et al., 2016; } \\
\text { Lorant et al., } 2018\end{array}$ & & & \\
\hline & CD82 & + & $\begin{array}{l}\text { Uezumi et al., 2016; } \\
\text { Sakai-Takemura et al., } 2018\end{array}$ & & & + & $\begin{array}{l}\text { Alexander et al., 2016; } \\
\text { Uezumi et al., 2016; Lorant } \\
\text { et al., } 2018\end{array}$ & + & Alexander et al., 2016 & \\
\hline
\end{tabular}




\begin{tabular}{|c|c|c|c|c|c|c|c|c|c|}
\hline & \multicolumn{4}{|c|}{ PSCs } & \multicolumn{2}{|r|}{ Adult muscle } & \multicolumn{2}{|r|}{ Fetal muscle } & \multirow{3}{*}{$\begin{array}{l}\text { Other sources } \\
\text { (see NOTE) }\end{array}$} \\
\hline & \multicolumn{2}{|r|}{ iPSCs } & \multicolumn{2}{|r|}{ ESCs } & \multirow[b]{2}{*}{ Presence } & \multirow[b]{2}{*}{ References } & \multirow[b]{2}{*}{ Presence } & \multirow[b]{2}{*}{ References } & \\
\hline & Presence & References & Presence & References & & & & & \\
\hline CD90 & + & Darabi et al., 2012 & + & Darabi et al., 2012 & $+/-$ & $\begin{array}{l}\text { (+): Morosetti et al., 2006; } \\
\text { Dellavalle et al., 2007; Zheng } \\
\text { et al., 2007; Crisan et al., } \\
\text { 2008; Lecourt et al., 2010; } \\
\text { Pisani et al., 2010b; Woodard } \\
\text { et al., 2014; Uezumi et al., } \\
\text { 2016; Lorant et al., } 2018 \\
\text { (-): Proksch et al., } 2009\end{array}$ & + & $\begin{array}{l}\text { Crisan et al., 2008; } \\
\text { Castiglioni et al., } 2014\end{array}$ & \\
\hline CD105 & $+/-$ & $\begin{array}{l}\text { (+): Awaya et al., 2012; } \\
\text { Darabi et al., } 2012 \\
(-) \text { : Sakai-Takemura et al., } \\
2018\end{array}$ & + & $\begin{array}{l}\text { Awaya et al., 2012; Darabi } \\
\text { et al., } 2012\end{array}$ & $+/-$ & $\begin{array}{l}\text { Lecourt et al., 2010; Pisani } \\
\text { et al., 2010b; Woodard et al., } \\
\text { 2014; Uezumi et al., 2016; } \\
\text { Lorant et al., } 2018 \\
\text { (-): Alessandri et al., } 2004\end{array}$ & + & Crisan et al., 2008 & $\begin{array}{l}\text { Wharton's jelly } \\
\text { (Conconi et al., } \\
\text { 2006) }\end{array}$ \\
\hline CD146 & +/low & $\begin{array}{l}\text { (+): Darabi et al., 2012; } \\
\text { Tedesco et al., } 2012 \\
\text { (Low): Sakai-Takemura et al., } \\
2018\end{array}$ & + & Darabi et al., 2012 & +/low & $\begin{array}{l}\text { (+): Cerletti et al., 2006; } \\
\text { Morosetti et al., 2006; } \\
\text { Dellavalle et al., 2007; Crisan } \\
\text { et al., 2008; Lecourt et al., } \\
\text { 2010; Pisani et al., 2010b; } \\
\text { Okada et al., 2012; Zheng } \\
\text { et al., } 2012 \\
\text { (Low): Lorant et al., } 2018\end{array}$ & + & $\begin{array}{l}\text { Cerletti et al., 2006; Lapan } \\
\text { et al., 2012; Alexander et al., } \\
\text { 2016; }\end{array}$ & $\begin{array}{l}\text { Placenta } \\
\text { (Park et al., } \\
\text { 2011) }\end{array}$ \\
\hline CD166 & + & Awaya et al., 2012 & + & $\begin{array}{l}\text { Awaya et al., 2012; Darabi } \\
\text { et al., } 2012\end{array}$ & + & Lecourt et al., 2010 & & & \\
\hline CD184 & $+/-$ & $\begin{array}{l}\text { (+): Borchin et al., } 2013 \\
(-) \text { : Awaya et al., 2012; } \\
\text { Darabi et al., } 2012\end{array}$ & $+/-$ & Awaya et al., 2012 & + & $\begin{array}{l}\text { Bareja et al., 2014; Marg } \\
\text { et al., 2014; Garcia et al., } \\
2018^{*}\end{array}$ & + & Castiglioni et al., 2014 & \\
\hline $\mathrm{CD} 271$ & + & $\begin{array}{l}\text { Hicks et al., 2017; } \\
\text { Sakai-Takemura et al., } 2018\end{array}$ & + & $\begin{array}{l}\text { (+): Borchin et al., } 2013 \text { (-): } \\
\text { Awaya et al., 2012; Darabi } \\
\text { et al., } 2012\end{array}$ & + & Sakai-Takemura et al., 2018* & + & $\begin{array}{l}\text { Alexander et al., 2016; Hicks } \\
\text { et al., } 2017\end{array}$ & \\
\hline CD318 & $+/-$ & $\begin{array}{l}\text { (+): Sakai-Takemura et al., } \\
2018 \\
(-) \text { : Uezumi et al., } 2016\end{array}$ & & & + & $\begin{array}{l}\text { Uezumi et al., 2016; Lorant } \\
\text { et al., 2018; Sakai-Takemura } \\
\text { et al., } 2018\end{array}$ & & & \\
\hline CD362 & + & Magli et al., 2017 & & & & & & & \\
\hline ErbB3 & + & $\begin{array}{l}\text { Hicks et al., 2017; } \\
\text { Sakai-Takemura et al., } 2018\end{array}$ & + & Hicks et al., 2017 & & & + & $\begin{array}{l}\text { Alexander et al., 2016; Hicks } \\
\text { et al., } 2017\end{array}$ & \\
\hline c-Met & $+/-$ & $\begin{array}{l}(+) \text { : Borchin et al., } 2013 \\
(-) \text { : Sakai-Takemura et al., } \\
2018\end{array}$ & + & Borchin et al., 2013 & & & & & \\
\hline HLA-ABC & + & Darabi et al., 2012 & + & Darabi et al., 2012 & & & & & \\
\hline ITGA7 & + & Darabi et al., 2012 & + & Darabi et al., 2012 & + & Castiglioni et al., 2014 & & & \\
\hline
\end{tabular}




PSC

PSCs

Fetal muscle

Other sources

(see NOTE)

iPSCs

ESCs

Presence References

Presence References

Presence References

Presence References
Negative CD15

marker

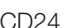

CD31

- $\quad$ Darabi et al., 2012; Tedesco et al., 2012

$\begin{array}{lll}\text { CD33 } & - & \text { Darabi et al., } 2012 \\ \text { CD34 } & - & \text { Awaya et al., 2012; Darabi }\end{array}$
et al., 2012 et al., 2012
- Wu et al., 2018
- $\quad$ Borchin et al., 2013; Choi

et al., 2016; Hicks et al.,

2017; Sakai-Takemura et al.,
- $\quad$ Lecourt et al., 2010; Pisani et al., 2010a; Agley et al.

2013

- Wu et al., 2018

- $\quad$ Alessandri et al., 2004; Dellavalle et al., 2007; Bareja et al., 2014; Charville et al., 2015; Xu et al., 2015; Garcia et al., 2018*; Lorant et al., 2018

Borchin et al., 2013

+/- $\quad$ (+): Hwang et al., 2014 (-): Awaya et al., 2012; Darab et al., 2012

- $\quad$ Darabi et al., 2012

\section{- Darabi et al., 2012} et al., 2008; Proksch et al.
+/- (+): Proksch et al., 2009; Pisani et al., 2010a; Okada

et al., 2012; Marg et al., 2014; Sidney et al., 2014

(-): Alessandri et al., 2004; Morosetti et al., 2006; Dellavalle et al., 2007; Zheng et al., 2007, 2012; Crisan et al., 2008; Negroni et al., 2009; Lecourt et al., 2010 ; Pisani et al., 2010b; Bareja et al., 2014; Charville et al., 2015; Franzin et al., 2016; Garcia et al., 2018*; Lorant et al., 2018

- $\quad$ Alessandri et al., 2004; Morosetti et al., 2006; Dellavalle et al., 2007; Crisan 2009; Lecourt et al., 2010; Okada et al., 2012; Zheng et al., 2012; Bareja et al. 2014; Charville et al., 2015; Xu et al., 2015; Garcia et al., 2018*; Lorant et al., 2018
- $\quad$ Cerletti et al., 2006; Castiglioni et al., 2014
(Park et al.,

2011)

Umbilical cord

blood

(Koponen et al.,

2007; Nunes

et al., 2007)

$\begin{array}{ll}\text { Crisan et al., 2008; } & \text { Placenta } \\ \text { Castiglioni et al., 2014, } & \text { (Park et al., } \\ \text { Franzin et al., 2016 } & \text { 2011) } \\ & \text { Umbilical cord } \\ & \text { blood } \\ & \text { (Nunes et al., } \\ & 2007)\end{array}$


the SMPC population (Wu et al., 2018). However, CD10 expression does not always correspond to SMPCs. A study using adult human muscle showed that $\sim 80 \%$ of $\mathrm{Pax}^{+}$cells expressed CD10, suggesting that not all adult satellite cells express CD10 (Wu et al., 2018). Human primary myoblasts also uniformly express CD10 ( 97\%) (Wu et al., 2018). When a $\mathrm{CD} 146^{+} / \mathrm{CD} 34^{-} / \mathrm{CD} 45^{-} / \mathrm{CD} 56^{-}$cell subset was isolated from multiple human organs, co-expression of CD10 was identified in the isolated cells (Crisan et al., 2008).

\section{CD13}

CD13 is also known as aminopeptidase $\mathrm{N}$, alanyl aminopeptidase or lamina-associated polypeptide 1 . This marker was initially found to regulate adhesion and differentiation of muscle satellite cells following ischemic injury in mice (Rahman et al., 2014). CD13 plays important roles for the migration of cancer and endothelial cells (Kehlen et al., 2003; Fukasawa et al., 2006). In the human brain, CD13 is expressed on capillary pericytes (Smyth et al., 2018). Although CD13 has not been studied much in the context of human myogenic cells, one study reported that human adult pericytes were almost homogeneously positive ( 97\%) for CD13 (Dellavalle et al., 2007). Positive CD13 expression has also been detected in SMPCs derived from human PSCs (Darabi et al., 2012; Tedesco et al., 2012), adult muscle (Morosetti et al., 2006; Dellavalle et al., 2007; Lecourt et al., 2010; Pisani et al., 2010b), and fetal muscle (Castiglioni et al., 2014). Similar to CD10, co-expression of CD13 was observed in the $\mathrm{CD} 146^{+} / \mathrm{CD}^{-} 4^{-} / \mathrm{CD} 45^{-} / \mathrm{CD} 56^{-}$cell subset isolated from multiple human organs (Crisan et al., 2008).

\section{CD29}

CD29, or integrin beta-1, is a well-established marker widely utilized to isolate or identify human myogenic cells. CD29 expression has been confirmed in PSC-derived SMPCs (Awaya et al., 2012; Darabi et al., 2012; Abujarour et al., 2014; Magli et al., 2017; Sakai-Takemura et al., 2018), fetal muscle (Castiglioni et al., 2014), postnatal muscle (Garcia et al., 2018), and adult muscle (Lecourt et al., 2010; Woodard et al., 2014; Charville et al., 2015; Xu et al., 2015; Lorant et al., 2018). An isoform of CD29, integrin beta-1D, has been shown to be severely reduced in patients with limb girdle muscular dystrophy type 2C (Anastasi et al., 2004) or sensitive-motor polyneuropathy (Anastasi et al., 2008). These results imply that normal levels of CD29 may be required for maintenance of healthy skeletal muscle.

In healthy adult skeletal muscle, all $\mathrm{Pax}^{+}$satellite cells displayed co-expression of CD56 and CD29, although a population of $\mathrm{CD}_{5} 6^{+} / \mathrm{CD} 29^{+}$cells without Pax7 expression was still identified (Xu et al., 2015). Compared to an unselected cell population, $\mathrm{CD} 6^{+} / \mathrm{CD} 29^{+}$cells exhibited a higher level of myofiber regeneration following cell transplantation into the pre-injured hindlimb muscle (tibialis anterior muscle) of immunodeficient NOD scid gamma (NSG) mice. In contrast, CD56 ${ }^{-} / \mathrm{CD} 29^{+}$cells showed insufficient or nonexistent myofiber regeneration (Xu et al., 2015). This study indicates that CD29 should be used in combination with other markers to define human SMPCs, as not only satellite cells but the myofiber and some non-muscle cells within skeletal muscle 
tissue also expressed CD29 (Xu et al., 2015). In a different study, when $\mathrm{CD} 31^{-} / \mathrm{CD} 34^{-} / \mathrm{CD} 45^{-} / \mathrm{CD} 29^{+} /$epidermal growth factor receptor $(\mathrm{EGFR})^{+}$cells were isolated from human adult skeletal muscle, these cells expressed a series of myogenic cell markers such as Pax7, Pax3, Myf5, MyoD, Myogenin, and Myocyte Enhancer Factor 2C. Further, the isolated cells can differentiate into myotubes in vitro and when transplanted into NSG mice (Charville et al., 2015). In contrast, the remaining fraction (i.e., unselected cells) did not give rise to any $\mathrm{Pax} 7^{+}$ cells and did not exhibit myogenic activity in culture, further supporting the notion that CD29 can indeed efficiently enrich myogenic cells when used in combination with other markers (Charville et al., 2015).

A study using an inducible gene expression system demonstrated that the expression of CD29/Integrin alpha-9 dimer $(\alpha 9 \beta 1)$ was upregulated in human PSCs following Pax7 induction (Magli et al., 2017). In this study, Pax7-overexpressing cells were tagged with a green fluorescent protein (GFP) reporter protein using a Pax7 promotor. When $\alpha 9 \beta 1^{+} / \mathrm{CD} 54^{+}$cells were isolated from Pax7-overexpressing PSCs, $\sim 95 \%$ of cells were CD362-positive, and nearly $100 \%$ of $\mathrm{GFP}^{+}$cells were triple positive $\left(\alpha 9 \beta 1^{+} / \mathrm{CD} 54^{+} / \mathrm{CD} 362^{+}\right)$. The triple positive cells demonstrated robust regenerative capacity in vivo, as human-specific satellite cells and myofibers were confirmed in the muscle of NSG mice at 10 months post-transplantation (Magli et al., 2017).

\section{CD44}

CD44 is also known as homing cell adhesion molecule, Pglycoprotein 1, lymphocyte homing receptor, extracellular matrix receptor III or HUTCH-1. The expression of CD44 is commonly seen in mesenchymal stem cells (MSCs) (Ramos et al., 2016), tenocytes (Scutt et al., 2008; Lui, 2015; Stolk et al., 2017), HSCs, and cancer stem cells (Thapa and Wilson, 2016; Senbanjo and Chellaiah, 2017). CD44 has also been detected on SMPCs from different cell sources, including PSCs (Darabi et al., 2012; Tedesco et al., 2012; Abujarour et al., 2014), adult muscle (Morosetti et al., 2006; Dellavalle et al., 2007; Lecourt et al., 2010; Pisani et al., 2010b; Lorant et al., 2018), and fetal muscle (Crisan et al., 2008; Castiglioni et al., 2014). Although CD44 expression in SMPCs was already verified in a number of previous works, this marker has not been tested to isolate or characterize human SMPCs by FACS. Interestingly, CD44 interacts with hyaluronan and activates EGFR signaling (Thapa and Wilson, 2016), which suggests that CD44 may play a significant role in the process of myogenesis through the EGFR-mediated pathway (Leroy et al., 2013). As an additional note, CD44 expression was identified in the endomysium of adult skeletal muscle (Lecourt et al., 2010).

\section{CD54}

CD54 (intercellular adhesion molecule 1, ICAM-1) is a glycoprotein typically expressed on endothelial cells and leukocytes (Zadeh et al., 2000; Long, 2011). CD54 expression is absent in healthy human muscle but detected in patients with inflammatory myopathies (Bartoccioni et al., 1994; De Bleecker and Engel, 1994; Marino et al., 2003). Treatment with various cytokines can induce CD54 expression in cultured human skeletal muscle cells (Goebels et al., 1992; Michaelis et al., 1993; Bartoccioni et al., 1994; Marino et al., 2001). One study reported that CD54 was upregulated by inducible Pax7 overexpression in human PSCs (Magli et al., 2017). Chromatin immunoprecipitation sequencing (ChIP-Seq) data revealed that Pax7 binds the $5^{\prime}$ region of the CD54 gene, suggesting that Pax7 directly regulates CD54 gene expression. Using the PSCs with inducible Pax 7 expression, CD54 ${ }^{+} / \mathrm{CD} 362^{+} /$integrin $\alpha 9 \beta 1^{+}$ cells were able to repopulate the satellite cell pool and generate new muscle fibers in an NSG mouse model at 10 months posttransplantation. In the same study, the potential of CD54 as a sole marker was also evaluated for SMPC isolation. When using the PSCs with a GFP reporter gene driven by a Pax7 promotor, GFP ${ }^{+}$ cells were highly enriched by CD54-based selection. Notably, the isolated cells exhibited robust muscle differentiation in vivo without any signs of teratoma formation even after 12 months of transplantation in NSG mice (Magli et al., 2017).

\section{CD56}

CD56, or neural cell adhesion molecule (NCAM), has been utilized for isolation and identification of human myogenic cells in an extensive list of publications. CD56 expression is observed on SMPCs derived from PSCs (Barberi et al., 2007; Awaya et al., 2012; Darabi et al., 2012; Goudenege et al., 2012; Albini et al., 2013; Abujarour et al., 2014; Hwang et al., 2014; Caron et al., 2016; Choi et al., 2016; Uezumi et al., 2016; Hicks et al., 2017; Rao et al., 2018; Sakai-Takemura et al., 2018) postnatal muscle (Garcia et al., 2018), adult muscle (Sinanan et al., 2004; Dellavalle et al., 2007; Zheng et al., 2007, 2012; Crisan et al., 2008; Lindström and Thornell, 2009; Negroni et al., 2009; Proksch et al., 2009; Lecourt et al., 2010; Pisani et al., 2010a; Okada et al., 2012; Agley et al., 2013; Bareja et al., 2014; Marg et al., 2014; Woodard et al., 2014; Xu et al., 2015; Alexander et al., 2016; Franzin et al., 2016; Uezumi et al., 2016; Lorant et al., 2018), fetal muscle (Castiglioni et al., 2014; Hicks et al., 2017), and placenta (Park et al., 2011).

It has been deduced previously that $\mathrm{CD} 56^{+} / \mathrm{Pax} 7^{-}$cells in adult muscle could represent activated satellite cells or myoblasts (Lindström and Thornell, 2009). Alongside other markers, CD56 expression has been used to enrich SMPCs, in which the isolated populations were able to form myotubes at high efficiency in vitro and/or contribute to muscle regeneration in vivo (Sinanan et al., 2004; Barberi et al., 2007; Dellavalle et al., 2007; Zheng et al., 2007, 2012; Crisan et al., 2008; Lecourt et al., 2010; Pisani et al., 2010a; Okada et al., 2012; Bareja et al., 2014; Castiglioni et al., 2014; Woodard et al., 2014; Xu et al., 2015; Alexander et al., 2016; Choi et al., 2016; Uezumi et al., 2016; Hicks et al., 2017; Lorant et al., 2018). CD56 expression was also used to identify and confirm SMPC fractions in the purified cells using other surface markers (Negroni et al., 2009; Proksch et al., 2009). Genetic analysis revealed that when compared to whole populations, both $\mathrm{CD}_{56}{ }^{+}$cultured fetal myocytes and human PSC-derived SMPCs highly expressed genes associated with myogenesis, embryonic development and cell migration (Hicks et al., 2017).

However, several other studies indicate that $\mathrm{CD}^{-}$ cells may also contain SMPCs. A population of


multiple human organs (Crisan et al., 2008) and placenta 
(Crisan et al., 2008; Park et al., 2011). The isolated cells, specifically named "perivascular cells" in these studies, were able to form multinucleated Myosin heavy chain $(\mathrm{MyHC})^{+} /$desmin $^{+} /$dystrophin $^{+}$myotubes in vitro as well as human spectrin ${ }^{+} /$human dystrophin $^{+}$myofibers and new blood vessels in vivo. After myogenic differentiation was induced in culture, these $\mathrm{CD} 146^{+} / \mathrm{CD} 34^{-} / \mathrm{CD} 45^{-} / \mathrm{CD} 56^{-}$ cells showed upregulated CD56 expression (Park et al., 2011). These cells were also able to differentiate into myotubes, chondrocytes, adipocytes and osteocytes upon appropriate inductions in culture (Crisan et al., 2008). In another report, CD $146^{+} / \mathrm{CD} 45^{-} / \mathrm{CD}^{-} 6^{-} / \mathrm{UEA}^{-1 \mathrm{R}^{-}}$cells could generate a high number of human spectrin ${ }^{+}$myofibers in an immunodeficient mouse model (Severe Combined Immunodeficiency, SCID; Zheng et al., 2012). Termed "endothelial cells" in the specific study, a CD $45^{-} / \mathrm{CD} 56^{-} / \mathrm{CD} 34^{+} / \mathrm{CD} 144^{+}$population derived from adult muscle formed $\mathrm{MyHC}^{+}$myotubes in vitro and a low number of human spectrin $^{+}$myofibers in vivo (Okada et al., 2012). More than half of these "endothelial cells" eventually expressed CD56 after expansion in culture (Okada et al., 2012).

The absence of CD56 expression may indicate diminished myogenic potential and increased adipogenic potential. In separate reports, $\mathrm{CD}_{5} 6^{-} / \mathrm{TE}-7^{+}, \mathrm{CD}^{-} 6^{-} / \mathrm{CD} 15^{+}$, $\mathrm{CD}_{56} / \mathrm{CD} 34^{+}$, and $\mathrm{CD} 56^{-} / \mathrm{CD} 34^{-}$cells derived from adult muscle were differentiated into adipoblasts but not myotubes (Zheng et al., 2007; Lecourt et al., 2010; Pisani et al., 2010a,b). When adult muscle-derived CD56-/CD29+ SMPCs were transplanted into NSG mice, human cell-derived myofibers were detected in only 1 out of 7 recipients, probably reflecting contamination with the $\mathrm{CD} 56^{+} / \mathrm{CD} 29^{+}$fraction or a very limited myogenic potential of $\mathrm{CD}^{-} 6^{-} / \mathrm{CD} 29^{+}$cells (Xu et al., 2015).

Based on these findings, CD56 expression seems to be identified in cells with a high capacity to differentiate into muscle, but if used alone may not work to enrich human SMPCs as a highly purified population.

\section{CD73}

Expression of CD73 (or ecto-5'-nucleotidase) has been detected in growth plates, articular cartilage, and hypertrophic chondrocytes (Coutu et al., 2017). CD73 is considered a marker of tenocytes (Lui, 2015; Stolk et al., 2017), MSCs (Ramos et al., 2016), vascular smooth muscle cells (Tamajusuku et al., 2006; Yang et al., 2015), and cancer cells (Gao et al., 2014). Although CD73 has not been frequently used for SMPC identification, its expression was found almost homogenously on SMPCs derived from several sources, including human PSCs (Awaya et al., 2012), MyoD-overexpressing human ESCs (Goudenege et al., 2012), and adult muscle (Woodard et al., 2014). These SMPCs expressed CD73, even though CD73 was not initially used for cell isolation (Crisan et al., 2008; Lecourt et al., 2010; Uezumi et al., 2016; Lorant et al., 2018). It has been reported that myogenic cells resided in the $\mathrm{CD}_{3}{ }^{+}$fraction of ESC-derived MSCs, and that these cells were able to differentiate into myotubes, adipocytes, chondrocytes and osteoblasts in vitro (Barberi et al., 2005, 2007).

\section{CD82}

CD82, also known as Tespan-27, is a member of the tetraspanin protein family primarily identified as a metastasis suppressor (Tonoli and Barrett, 2005). Recently, CD82 has become a popular marker to use in identifying SMPCs, as this cell surface protein is expressed on SMPCs derived from human PSCs (Uezumi et al., 2016; Sakai-Takemura et al., 2018), adult muscle (Alexander et al., 2016; Uezumi et al., 2016; Lorant et al., 2018) and fetal muscle (Alexander et al., 2016). In healthy adult muscle, CD82 was detected on $\sim 97 \%$ of $\mathrm{Pax}^{+}$or M-cadherin ${ }^{+}$satellite cells and a small number of interstitial cells (Uezumi et al., 2016). CD82 expression is also maintained in activated and differentiating myogenic cells (Alexander et al., 2016). This marker can be used alone to enrich SMPCs with high regenerative capacity posttransplantation (Uezumi et al., 2016). When this marker was used alongside CD146 and CD56 on separate occasions, increased myogenic activity was observed in the CD82 $2^{+}$fractions both in vitro and in vivo (Alexander et al., 2016; Uezumi et al., 2016).

Recent studies support the idea that CD82 may play significant roles during the process of myogenesis. Overexpression of CD82 molecules enhanced muscle differentiation in primary myoblasts (Alexander et al., 2016), whereas its downregulation decreased their proliferation and differentiation (Alexander et al., 2016; Uezumi et al., 2016). In $\mathrm{CD}^{+} 6^{+} / \mathrm{CD} 82^{+}$myogenic cells purified from human muscle, knockdown of CD82 increased the transcription of MyoD1 and Myogenin and led to premature differentiation even under culture conditions ideal for cell growth (Uezumi et al., 2016). Interestingly, a p38 inhibitor could suppress upregulation of MyoD1 and Myogenin induced by CD82 knockdown. These results implicate that CD82 likely regulates the balance between differentiation and self-renewal of SMPCs via a p38-mediated signaling pathway (Uezumi et al., 2016). CD82 forms a protein complex with integrin $\alpha 7 \beta 1$ and $\alpha$-sarcoglycan, both of which have been linked to muscle disorders (Alexander et al., 2016). The muscles from patients with Duchenne muscular dystrophy (DMD) commonly showed a reduced expression of CD82, which suggests that this molecule may play essential roles of SMPC function in the process of muscle degeneration (Alexander et al., 2016).

\section{CD90}

CD90/Thy1 is a glycophosphatidylinositol-anchored glycoprotein frequently used as an MSC marker (Ramos et al., 2016). CD90 is also expressed on tenocytes (Scutt et al., 2008; Lui, 2015; Stolk et al., 2017), endothelial cells, HSCs, and in developing nervous tissues (Wetzel et al., 2004). A number of studies reported that CD90 expression was detected in SMPCs derived from human PSCs (Darabi et al., 2012), adult muscle (Morosetti et al., 2006; Dellavalle et al., 2007; Zheng et al., 2007; Proksch et al., 2009; Lecourt et al., 2010; Pisani et al., 2010b; Woodard et al., 2014; Uezumi et al., 2016; Lorant et al., 2018), and fetal muscle (Crisan et al., 2008; Castiglioni et al., 2014). In human adult muscle, $\mathrm{CD} 90^{+}$cells were also identified in the endomysium and adventitia of venous blood vessels (Lecourt et al., 2010). When culture-expanded satellite cells were sorted into $\mathrm{CD}_{3} 4^{+} / \mathrm{CD} 0^{-}, \mathrm{CD} 34^{-} / \mathrm{CD}{ }^{-}$, and $\mathrm{CD} 34^{-} / \mathrm{CD} 90^{+}$ 
fractions, all three fractions expressed myogenic markers (Myf-5, MyoD, and Myogenin) as well as endothelial markers (CD31 and von Willebrand factor) (Proksch et al., 2009). Although CD90 expression was confirmed throughout various types of SMPCs, it remains inconclusive whether CD90 alone could represent the entirety of the SMPC population.

\section{CD105}

CD105 (endoglin, Src Homology 2) is a well-acknowledged marker of endothelial cells. This molecule plays a crucial role in angiogenesis and tumor growth (Fonsatti et al., 2010). Not limited to endothelial cells, the expression of CD105 is also identified in various types of SMPCs. This includes SMPCs derived from PSCs (Awaya et al., 2012; Darabi et al., 2012), adult muscle (Alessandri et al., 2004; Lecourt et al., 2010; Pisani et al., 2010b; Woodard et al., 2014; Uezumi et al., 2016; Lorant et al., 2018), and fetal muscle (Crisan et al., 2008), although the level of CD105 expression ranged widely from rare to ubiquitous in different types of progenitor cells. In adult muscle, CD105 was expressed in the sinusoidal endothelium and endomysium (Lecourt et al., 2010; Coutu et al., 2017). When $\mathrm{CD} 105^{+} / \mathrm{CD} 31^{-} / \mathrm{KDR}^{-}$cells were isolated from Wharton's jelly (a gelatinous substance within the umbilical cord) and implanted into the muscle of Lewis male rats, the grafted cells were positive with sarcomeric tropomyosin, a protein that regulates muscle contraction, at 2 weeks post-transplantation (Conconi et al., 2006). These results indicate that the grafted $\mathrm{CD} 105^{+}$ cells could generate functional muscle fibers. Further, these


myotubes, adipocytes and osteoblasts in vitro. In other studies, CD105 was also found on human tenocytes (Lui, 2015; Stolk et al., 2017). As such, CD105 may likely be indicative of mesodermal progenitor cells with multilineage potential.

\section{CD146}

CD146 (or melanoma cell adhesion molecule, MCAM) is wellstudied for its important role in development, cell migration, immunology, angiogenesis, cancer progression, and myogenesis (Wang and Yan, 2013). In adult muscle, CD146 expression has been observed in the endomysium (Lecourt et al., 2010). In fetal skeletal muscle, $\mathrm{CD} 146^{+}$cells were found adjacent to myofibers and within blood vessels. These $\mathrm{CD} 146^{+}$cells were also positive for M-Cadherin, Pax7, and MyoD (Cerletti et al., 2006).

CD146 expression has been detected on SMPCs derived from PSCs (Darabi et al., 2012; Tedesco et al., 2012; Sakai-Takemura et al., 2018), adult muscle (Cerletti et al., 2006; Morosetti et al., 2006; Dellavalle et al., 2007; Crisan et al., 2008; Lecourt et al., 2010; Pisani et al., 2010b; Okada et al., 2012; Zheng et al., 2012; Lorant et al., 2018), fetal muscle (Cerletti et al., 2006; Crisan et al., 2008; Lapan et al., 2012; Alexander et al., 2016), and placenta (Park et al., 2011). It has been reported that the CD146 ${ }^{+}$fraction of SMPCs derived from adult muscle, fetal muscle and placenta contained cells with higher myogenic potential (Cerletti et al., 2006; Crisan et al., 2008; Park et al., 2011; Zheng et al., 2012; Alexander et al., 2016).

When both SP and main population (MP) cells were selected from human fetal muscle cells by scatter gating following
FACS analysis, the CD146-based selection could enrich a population of myogenic cells. However, freshly isolated cells remained heterogenous: only $\sim 50 \%$ of $\mathrm{CD}_{146^{+}} \mathrm{SP}$ and $\mathrm{MP}$ cells expressed Pax7, Myf5, or MyoD (Lapan et al., 2012). If SP and MP cells were sorted based on CD146 expression and then maintained in culture conditions that favored muscle differentiation, only $\mathrm{CD}_{146^{+}}$cell populations showed myotube formation. Interestingly, the highest number of myotube-positive cells was observed in the $\mathrm{CD}_{146^{+}} \mathrm{SP}$ fraction. Furthermore, CD146 ${ }^{-}$cell fractions subsequently acquired CD146 expression during expansion in culture but did not acquire myogenic potential (Lapan et al., 2012). These observations suggest that myogenic lineage enrichment based on CD146 may only be useful for freshly isolated cells. When transplanted into NOD mice, $\mathrm{CD}_{146^{+}} \mathrm{SP}$ cells exhibited high muscle regenerative capacity and gave rise to new human muscle fibers, whereas $\mathrm{CD}_{146^{+}}$total cells (i.e., a population containing both MP and SP cells) and CD146 ${ }^{+} \mathrm{MP}$ cells showed low engraftment rate (Lapan et al., 2012).

\section{CD184}

CD184, or commonly recognized as $\mathrm{C}-\mathrm{X}-\mathrm{C}$ chemokine receptor type 4 (CXCR-4), is a molecule with potent chemotactic activity for lymphocytes. It is crucial for homing hematopoietic stem cells to their adult marrow (Villa et al., 2012). CD184 is widely expressed on blood cells, endothelial cells, and neural cells (Walenkamp et al., 2017). CD184 expression is also confirmed on PSC-derived SMPCs (Borchin et al., 2013) as well as in adult muscle (Bareja et al., 2014; Marg et al., 2014; Garcia et al., 2018) and fetal muscle (Castiglioni et al., 2014).

As CD184 is also expressed in neural cells (Kos et al., 1999) and definitive endoderm cells (Teo et al., 2012), a combination of CD184 and other cell markers would be necessary to eliminate these non-myogenic cell types in PSC-derived cell populations. For instance, one study used the depletion of $\mathrm{CD} 7^{+}$cells and $\mathrm{c}-\mathrm{Met}^{-}$cells to sufficiently exclude neural cells among the CD184 ${ }^{+}$cell population (Borchin et al., 2013). In this study, $\mathrm{CD}^{-} 7^{-}$/acetylcholine receptor $(\mathrm{AChR})^{-}$cells were purified from differentiated PSCs and then sorted into

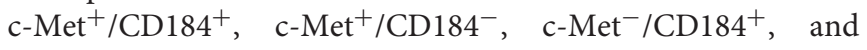


immediately after sorting revealed that both $\mathrm{c}-\mathrm{Met}^{+} / \mathrm{CD} 184^{+}$ and $\mathrm{c}-\mathrm{Met}^{+} / \mathrm{CD} 184^{-}$fractions contained highly pure SMPCs. In contrast, $\mathrm{c}^{-\mathrm{Met}^{-}} / \mathrm{CD} 184^{+}$fraction contained both SMPCs

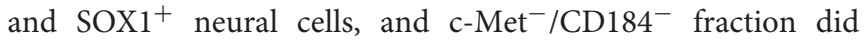
not have any SMPCs. Although CD184 alone could not enrich SMPCs, CD184 expression may be indicative of myogenic



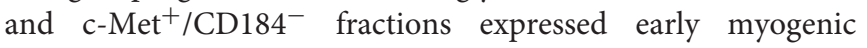
genes Six 4 and Pax3 (paralogue of Pax7) at day 23 of postmyogenic differentiation of PSCs (Borchin et al., 2013). Both c-Met $^{+} / \mathrm{CD} 184^{+}$and c-Met ${ }^{+} / \mathrm{CD} 184^{-}$cells gradually acquired Pax7 expression by day 25, and almost all these cells exhibited co-expression of Pax3 and Pax7 by day 35. At this point, the number of Pax7-positive cells was higher in c-Met ${ }^{+} / \mathrm{CD} 184^{+}$ cells compared to c-Met ${ }^{+} / \mathrm{CD} 184^{-}$cells, while $97-98 \%$ of cells still retained Pax3 expression in both preparations. As Pax7 has 
been considered a later-stage marker of myogenic progenitors compared to Pax 3 , a specific population in $\mathrm{c}-\mathrm{Met}^{+} / \mathrm{CD} 184^{+}$cells might have proceeded farther along the differentiation process. On the other hand, $\mathrm{c}-\mathrm{Met}^{+} / \mathrm{CD} 184^{-}$cells might represent a more primitive SMPC population than $\mathrm{c}-\mathrm{Met}^{+} / \mathrm{CD} 184^{+}$cells. Furthermore, gene-expression analysis confirmed the presence of Pax3 and Pax7 mRNA transcripts together with LBX1 in both c-Met ${ }^{+} / \mathrm{CD} 184^{+}$and c-Met ${ }^{+} / \mathrm{CD} 184^{-}$sorted populations. These in vitro results seem to be consistent with the situations observed during in vivo muscle development: within the hypaxial domain of the embryonic dermomyotome, the delamination of $\mathrm{Pax}^{+} / \mathrm{LBX}^{+}$migratory muscle precursors is dependent on c-Met expression (Bladt et al., 1995; Dietrich et al., 1999), whereas CD184 is essential for the subsequent survival and distribution of precursors at the site of migration (Vasyutina et al., 2005; Buckingham, 2006).

\section{CD271}

CD271, also known as p75 neurotrophin receptor or lowaffinity nerve growth factor receptor (p75NGFR), has recently been recognized as a positive marker to identify SMPCs and MSCs (Álvarez-Viejo et al., 2015; Sakai-Takemura et al., 2018). This surface marker was first reported as a candidate SMPC marker in a study when CD271 expression was detected in culture-expanded postnatal myoblasts but not in fibroblasts (Sakai-Takemura et al., 2018). When terminally differentiated, myotubes were exclusively formed in the $\mathrm{CD} 271^{+}$fraction of iPSC-derived SMPCs although some CD271 ${ }^{+}$cells remained non-myogenic (Sakai-Takemura et al., 2018). The progenitor cells sorted with a combination of $\mathrm{CD} 271^{+}$and other markers $\left(\mathrm{CD} 7^{-} / \mathrm{CD} 108^{-} / \mathrm{ErbB}^{+}\right)$were able to generate myofibers with high efficiency in vitro and in vivo (Sakai-Takemura et al., 2018). The other group prepared CD271 ${ }^{+}$SMPCs from DMD patient-derived iPSCs (DMD iPSCs) that had been genetically corrected by CRISPR/Cas9 technology. These CD271 ${ }^{+}$SMPCs exhibited superior myotube-forming potential; even higher than the cells in the $\mathrm{CD}_{56}{ }^{+}, \mathrm{CD} 146^{+}$, or $\mathrm{CD} 184^{+}$fractions (Hicks et al., 2017). In a different study, SMPCs derived from four human PSC lines (ESCs, wild type iPSCs, DMD iPSCs, and genetically corrected DMD iPSCs) commonly expressed CD271 and ErbB3. These $\mathrm{CD} 271^{+} / \mathrm{ErbB}^{+}$cells displayed significantly higher expression of myogenic genes and increased efficiency of skeletal muscle differentiation (Hicks et al., 2017). When using genetically corrected DMD iPSC-derived CD271 ${ }^{+}$cells, the cells showed better engraftment in the muscle of dystrophin-deficient NSG mice compared to CD56 ${ }^{+}$cells (Hicks et al., 2017).

At early developmental stages before any other myogenic surface markers are presented on muscle progenitors, CD271/ErbB3-based isolation can be used to enrich $\mathrm{Pax} 7^{+}$ cells and $\mathrm{Myf}^{+}$cells from human fetal muscles (Hicks et al., 2017). At 8 weeks of gestation, a $\mathrm{CD} 271^{+} / \mathrm{ErbB}^{+}{ }^{+}$subpopulation emerged in the muscle with expression of myogenic transcription factors. At 11 weeks, the $\mathrm{CD} 271^{+} / \mathrm{ErbB}^{+}$subpopulation began to co-express some cell surface markers such as CD56, CD82, and CD146. These cells then started losing CD271 expression at 16 weeks of gestation. When $\mathrm{CD} 271^{+} / \mathrm{ErbB}^{+}$cells were isolated at this time point, plated down, and differentiated in culture, the cells could form myotubes with nearly $100 \%$ efficiency in cell fusion (Hicks et al., 2017). Such changes of CD271 expression have been characterized during transitions from early to late waves of human fetal myogenesis, which also correlates to the development of primary limb myofibers or maturation of secondary fetal myofibers (Hicks et al., 2017). CD271/ErbB3 expression can be used to distinguish premature SMPCs from more committed $\mathrm{MyoD}^{+}$myocytes (Hicks et al., 2017). Together, these data supports the idea that $\mathrm{CD} 271$ can be used as a positive selection marker to enrich human PSC-derived SMPCs.

However, we should bear in mind that CD271 expression may not always correlate to a capacity of muscle differentiation in human PSC-derived SMPCs. A recent study, which had used a double reporter ESC line driven by Pax7 and Myf5 promoter genes, revealed that $\mathrm{CD} 271^{+} / \mathrm{ErbB}^{+}, \mathrm{CD} 271^{+} / \mathrm{ErbB}^{-}$, and $\mathrm{CD} 271^{-} / \mathrm{ErbB}^{+}$fractions contained similar proportions of $\mathrm{Pax}^{+}$and $\mathrm{Myf5}^{+}$cells (Wu et al., 2018). When $\mathrm{CD}_{271^{+}} / \mathrm{ErbB}^{+}{ }^{+}, \mathrm{CD}_{271^{+}} / \mathrm{ErbB}^{-}$, and $\mathrm{CD} 271^{-} / \mathrm{ErbB}^{+}{ }^{+}$ fractions were sorted from Pax7/Myf5 dual reporter ESCs and terminally differentiated in vitro, all three fractions exhibited similar proportions of $\mathrm{MyHC}^{+}$cells and displayed similar myotube formation efficiency (Wu et al., 2018).

\section{ErbB3}

As mentioned in the previous section, ErbB3 has also been used as a surface marker to efficiently purify human PSCderived SMPCs (Hicks et al., 2017; Sakai-Takemura et al., 2018). ErbB3, also known as human epidermal growth factor receptor 3 , is widely expressed in a variety of organs during human development, including skin, bone, muscle, nervous system, lungs, and intestines (Coussens et al., 1985). ErbB3 is also expressed in human fetal $\mathrm{CD} 146^{+}$cells which demonstrate high myogenic capacity (Alexander et al., 2016). When iPSC-derived SMPCs were sorted solely based on ErbB3 expression, myotubes were exclusively formed in the enriched $\mathrm{ErbB}^{+}$population following terminal differentiation in culture (Sakai-Takemura et al., 2018). ErbB3-based cell sorting could enrich myogenic cells much more efficiently compared to the isolation using a combination of CD56 and CD82 expression (Sakai-Takemura et al., 2018). In a different study, isolated iPSC-derived SMPCs with $\mathrm{CD} 7^{-} / \mathrm{CD} 108^{-} / \mathrm{CD} 271^{+} / \mathrm{ErbB}^{+}{ }^{+}$or $\mathrm{CD} 271^{+} / \mathrm{ErbB}^{+}$ were able to differentiate into myotubes with high efficiency in culture and in vivo (Sakai-Takemura et al., 2018). In a similar study using genetically corrected DMD iPSC-derived SMPCs, $\mathrm{ErbB}^{+}$cells displayed high potential for myotube formation compared to the cells solely sorted by CD56, CD146, CD184, or CD271 expression (Hicks et al., 2017). When ErbB3 ${ }^{+}$cells were prepared from four PSC lines (ESCs, wild type iPSCs, DMD iPSCs, and genetically corrected DMD iPSCs), all ErbB3 ${ }^{+}$ cells from the four PSC lines were positive with CD271. These $\mathrm{ErbB}^{+} / \mathrm{CD} 271^{+}$SMPC lines exhibited higher capacity for muscle differentiation than double-negative fractions (Hicks et al., 2017). When iPSC-derived SMPCs were transplanted into the limb muscle of dystrophin-deficient NSG mice, the implanted cells promoted significant engraftment and restored dystrophin expression in the grafted area (Hicks et al., 2017). 
As we already introduced in the section on CD271, CD271/ErbB3 expression can be used to enrich $\mathrm{Pax}^{+}$ and $\mathrm{Myf5}^{+}$cells from fetal muscles at the first and second trimesters of human development (Alexander et al., 2016). A CD271 ${ }^{+} /$ErbB3 $^{+}$subpopulation began to emerge in fetal muscle at 8 weeks of gestation and gradually increased the expression of myogenic genes (Hicks et al., 2017).

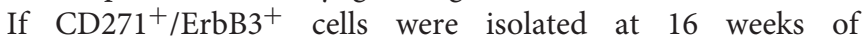
gestation, the cells could differentiate into myotubes with a fusion efficiency close to $100 \%$ when plated down and differentiated in culture (Hicks et al., 2017). The changes in $\mathrm{CD} 271^{+} / \mathrm{ErbB}^{+}$expression possibly mark the progression of human fetal myogenesis.

Similar to CD271, ErbB3 expression is not always indicative of higher myogenic potential in human PSCderived SMPCs. In another study, ESC-derived cells were sorted to three fractions based on CD271 and ErbB3 expression $\left(\mathrm{CD} 271^{+} / \mathrm{ErbB}^{+}, \mathrm{CD} 271^{+} / \mathrm{ErbB}^{-}\right.$, and $\mathrm{CD}^{\left.271^{-} / \mathrm{ErbB}^{+}\right)}$ and then myogenic differentiation was induced. Among the three fractions, there was no difference in the number of $\mathrm{Pax}^{+}$cells and $\mathrm{Myf5}^{+}$cells (Wu et al., 2018). When ESC-derived Pax7/Myf5 double reporter cells were sorted into three fractions and the cells in these fractions were plated for myotube differentiation, neither the efficiency of myotube formation nor the percentage of $\mathrm{MyHC}^{+}$ cells were different when compared between three fractions (Wu et al., 2018).

\section{CD318}

CD318, also known as CUB domain-containing protein 1 (CDCP1) or transmembrane and associated with Src kinases (TRASK), is present on epithelial cells (Spassov et al., 2009), hematopoietic cells (Conze et al., 2003), MSCs (Buhring et al., 2004), and tumor cells (Uekita and Sakai, 2011). Some recent studies reported CD318 expression in myogenic cells. In satellite cells, cytoplasmic expression of CD318 was detected in $\sim 75 \%$ of total cells (Uezumi et al., 2016). $\mathrm{Pax} 7^{+} / \mathrm{MyoD}^{+}$adult musclederived SMPCs grown in hypoxic conditions were reportedly only found in the CD $318^{+}$fraction (Uezumi et al., 2016). In mice, satellite cells and myofibers positive with human cell specific markers were observed in recipients of $\mathrm{CD} 318^{+}$adult musclederived cells, but rarely in recipients of CD318 ${ }^{-}$cells (Uezumi et al., 2016). In contrast, it remains controversial whether CD318 can specifically identify SMPC pools in differentiated human iPSCs. To date, both the presence (Sakai-Takemura et al., 2018) and absence (Uezumi et al., 2016) of CD318 expression have been reported in two different studies. Such controversial results in CD318 expression may be caused by differences in culture conditions like oxygen concentration, as several studies demonstrated that CD318 expression was changed by hypoxia (Razorenova et al., 2011; Emerling et al., 2013; Cao et al., 2015). Since commercially available myoblasts and iPSC-derived cells cultured in normoxic conditions showed diminished or undetectable CD318 expression, CD318-based sorting failed to enrich myogenic cells in iPSC-derived SMPCs (Uezumi et al., 2016).

\section{Negative Surface Markers for Human SMPCs}

The negative markers listed in Table $\mathbf{1}$ are typically absent on human SMPCs but mainly present on non-myogenic cell types. As the markers on their own are usually not indicative of SMPC properties, the cells positive with these markers should be depleted during SMPC isolation. In other words, a majority of SMPCs reside in the negative fraction of these markers. In this section, several representatives of negative surface markers are introduced.

\section{CD15}

CD15 (3-fucosyl-N-acetyl-lactosamine, Lewis X or stage-specific embryonic antigen 1) has been used to separate myogenic and adipogenic cells. $\mathrm{CD}_{1} 5^{+}$cells can be found outside adult muscle fibers (Lecourt et al., 2010); more specifically, in the interstitial position between the basal lamina of adjacent myofibers (Pisani et al., 2010a). Based on recent observations, CD15 seems to be negative in a majority of SMPCs because $\mathrm{CD} 15$ is predominantly detectable in the adipogenic cells with relatively less myogenic capacity. Cell sorting by CD56 and $\mathrm{CD} 15$ expression $\left(\mathrm{CD} 56^{+} / \mathrm{CD} 15^{-}, \mathrm{CD} 56^{-} / \mathrm{CD} 15^{+}\right.$, and $\mathrm{CD} 6^{+} / \mathrm{CD} 15^{+}$) could distinguish three cell types: myogenic cells without adipogenic capabilities, non-myogenic cells with adipogenic capabilities, and myogenic cells with adipogenic capabilities, respectively (Lecourt et al., 2010; Pisani et al., 2010a; Agley et al., 2013). $\mathrm{CD}^{+} 6^{+} / \mathrm{CD} 15^{+}$cells were still able to retain muscle differentiation capacity even under conditions that strongly favor adipogenesis (Agley et al., 2013).

\section{CD24}

Known as a sialoglycoprotein and a cell adhesion molecule, CD24 is commonly expressed on the cellular membrane of B lymphocytes and neutrophils (Elghetany and Patel, 2002; Tan et al., 2016), as well as on neural progenitors (Poncet et al., 1996; Fang et al., 2017; Gilliam et al., 2017). Depletion of CD24-expressing cells can enrich human PSC-derived SMPCs when used in combination with positive selection of $\mathrm{CD} 10^{+}$ cells. When $\mathrm{CD} 10^{+} / \mathrm{CD} 24^{-}$cells were enriched from a variety of PSC lines (Pax7/Myf5 double reporter ESCs, two reporterfree ESC lines, and one reporter-free iPSC line), the isolated cells showed a high level of myotube formation following terminal differentiation (Wu et al., 2018). CD24 expression was not detectable in primary myoblasts (Wu et al., 2018). Interestingly, specific deletion of Myogenin in adult SMPCs resulted in a 10-fold downregulation of CD24 (Meadows et al., 2008). At 16 and 19 weeks of human gestation, a specific cell population with strong CD24 expression was identified in the mesenchymal areas adjacent to developing muscles and intramuscular nerves (Figarella-Branger et al., 1993). In adult muscles, CD24 expression was identified in some unmyelinated nerve fibers and interstitial elongated cells near the neuromuscular junctions (Figarella-Branger et al., 1993). CD24-positive signals were also detected in regenerating muscle fibers following segmental necrosis (Figarella-Branger et al., 1993). These in situ locations of CD24 expression implicate that $\mathrm{CD} 24$ is possibly involved in the development, maintenance, 
and regeneration of muscle innervation. In mice, CD24 is expressed by myofiber synaptic nuclei and plays a role in synaptic transmission (Jevsek et al., 2006).

\section{CD31}

CD31, specifically named platelet endothelial cell adhesion molecule (PECAM-1), is a member of the immunoglobulin superfamily. CD31 is primarily used to detect endothelial cells (Lertkiatmongkol et al., 2016). For SMPC purification, this surface marker has been used as a negative selector. In a number of different studies, a depletion step of $\mathrm{CD} 1^{+}$cells has been applied to isolate SMPCs from adult muscle (Bareja et al., 2014; Xu et al., 2015; Garcia et al., 2018) and fetal muscle (Cerletti et al., 2006; Castiglioni et al., 2014). In adult muscle, CD31 expression was observed in the endomysium and intimae part of arteries (Lecourt et al., 2010). In a previous study using fetal muscle, both $\mathrm{CD} 146^{+} / \mathrm{CD} 31^{+}$and $\mathrm{CD} 146^{+} / \mathrm{CD} 31^{-}$cells were found adjacent to myofibers, and some $\mathrm{CD} 146^{+} / \mathrm{CD} 31^{+}$were clearly located within blood vessels (Cerletti et al., 2006). When these cells were isolated from the tissues and cultured, both $\mathrm{CD} 146^{+} / \mathrm{CD} 31^{+}$and $\mathrm{CD} 146^{+} / \mathrm{CD} 31^{-}$cells were positive with myogenic markers such as Pax7, MyoD, and desmin. Notably, both cell types were able to differentiate into $\mathrm{MyHC}^{+}$myotubes. These results suggest that CD31 expression itself would not correspond to the ability of muscle differentiation in isolated cells (Cerletti et al., 2006).

\section{CD34}

Although CD34 has been considered as a marker of satellite cells in mice, it does not mark satellite cells in human muscle (Péault et al., 2007). CD34 has been used in human muscle satellite cells for negative selection (Sidney et al., 2014). This surface protein has often been utilized for human SMPC isolation as a negative selection marker along with a combination with other surface markers (Zheng et al., 2007; Crisan et al., 2008; Proksch et al., 2009; Pisani et al., 2010b; Okada et al., 2012; Bareja et al., 2014; Castiglioni et al., 2014; Garcia et al., 2018). CD34 is a transmembrane phosphoglycoprotein and widely accepted as a marker of hematopoietic lineage (Sidney et al., 2014). However, CD34 expression is also detected on various types of non-hematopoietic cells such as MSCs (Huss, 2000; Lin et al., 2012), interstitial cells (Popescu et al., 2007; Rasmussen et al., 2007; Zheng et al., 2007; Yu et al., 2012), epithelial progenitors (Blanpain et al., 2004), vascular endothelial progenitors (Fina et al., 1990), and corneal keratocytes (Poole et al., 1993; Polisetty et al., 2008). Although several publications reported CD34 expression in muscle satellite cells (Sidney et al., 2014) and other myogenic cells (Zheng et al., 2007; Proksch et al., 2009; Pisani et al., 2010a; Okada et al., 2012), it remains controversial whether this marker itself is commonly detectable in different types of SMPCs from various sources. Nonexistent or low levels of CD34 expression were detected in human SMPCs derived from PSCs (Awaya et al., 2012; Darabi et al., 2012; Hwang et al., 2014), adult muscle (Alessandri et al., 2004; Morosetti et al., 2006; Dellavalle et al., 2007; Negroni et al., 2009; Lecourt et al., 2010; Zheng et al., 2012; Charville et al., 2015; Franzin et al., 2016; Lorant et al., 2018), fetal muscle (Castiglioni et al., 2014), umbilical cord blood (Koponen et al., 2007; Nunes et al., 2007), and placenta
(Park et al., 2011). In skeletal muscle, CD34 expression represents an endothelial nature due to the detection of $\mathrm{CD} 34^{+}$cells in the endomysium and interstitial spaces (Hollemann et al., 2008; Lecourt et al., 2010; Pisani et al., 2010b). CD34 expression has also been detected in the blood vessels within skeletal muscle, particularly the tunica adventitia in veins and the tunica media in arteries (Lecourt et al., 2010).

Evidence in previous studies suggests that both $\mathrm{CD} 34^{+}$and CD34- cells were present in SMPC pools, but the CD34- cell population seemed to be more homogeneous and committed to the myogenic lineage compared to $\mathrm{CD} 34^{+}$cells. For instance, some groups of SMPCs have been confirmed as $\mathrm{CD} 34^{-}$ populations, which include proliferative and activated satellite cells $\left(\mathrm{CD} 34^{-} / \mathrm{CD} 6^{+} / \mathrm{Myf5}^{+}\right.$cells), and a minority of pericytes and mesoangioblasts with adipogenic potential $\left(\mathrm{CD} 34^{-} / \mathrm{CD} 56^{-}\right.$ cells) (Péault et al., 2007). In contrast, $\mathrm{CD}_{4} 4^{+}$cells might contain several cell populations originated from the interstitial compartment in skeletal muscle, such as myoendothelial cells, endothelial cells, and SP cells. Interstitial $\mathrm{CD} 34^{+}$cells may have been derived from resident endothelial cells (Vailhe et al., 2001) or have invaded skeletal muscle directly via circulation (Asahara and Kawamoto, 2004). Typically, CD34- cells show consistent myogenic potential across different preparations of SMPCs, whereas myogenic potential in $\mathrm{CD}_{3} 4^{+}$cells tends to be inconsistent and shows variation in different preparations of SMPCs.

A series of studies using adult muscle-derived MDSCs also supports the efficiency of CD34-based isolation to enrich homogenous myogenic cells in the negative fraction. Regardless of muscle type and culture period, CD34 ${ }^{-}$MDSCs displayed high expression of myogenic markers (Myf5, Pax7, MyoD, myogenin, desmin, and muscle creatine kinase) (Pisani et al., 2010b). These CD34- MDSCs consistently expressed CD56 and showed myogenic potential following differentiation (Pisani et al., 2010b). In contrast, CD34 ${ }^{+}$MDSCs barely expressed these myogenic markers and exhibited inconsistent myogenic potential across different preparations of MDSCs (Pisani et al., 2010b). When MDSCs were sorted into CD $34^{-} / \mathrm{CD} 90^{+}, \mathrm{CD} 34^{-} / \mathrm{CD} 90^{-}$ and $\mathrm{CD} 34^{+} / \mathrm{CD} 90^{-}$fractions, $\mathrm{CD} 34^{+} / \mathrm{CD} 90^{-}$cells showed the lowest expression of Myf5, MyoD, and Myogenin (Proksch et al., 2009). Consistently, in a different study using CD133 ${ }^{+}$ myoblasts isolated from adult muscle, $\mathrm{CD} 133^{+} / \mathrm{CD} 34^{-}$cells exhibited higher CD56 expression in culture compared to $\mathrm{CD} 33^{+} / \mathrm{CD} 34^{+}$cells (Negroni et al., 2009). In another study, $\mathrm{CD} 34^{-} / \mathrm{CD} 56^{+} / \mathrm{CD} 144^{-}$cells also retained a high level of CD56 even after expansion in culture, whereas these cells also maintained a myogenic and endothelial cell phenotype (Okada et al., 2012). Interestingly, CD34- MDSCs did not show adipogenic differentiation both in vitro and in vivo, whereas $\mathrm{CD}_{3} 4^{+}$cells were able to generate adipocytes both in culture and following transplantation (Pisani et al., 2010b). $\mathrm{CD}^{+} 4^{+}$MDSCs may retain cellular characteristics as multipotent stem cells, which possibly implies their limited commitment to myogenic lineage.

Although CD $34^{+}$cells do not specifically represent SMPC pools, these cells may have supporting roles for the integration of SMPCs when transplanted with $\mathrm{CD}_{3} 4^{+}$SMPCs. In one 
study, three cell populations $\left(\mathrm{CD} 56^{+} / \mathrm{CD} 34^{+} / \mathrm{CD} 144^{+}\right.$, $\mathrm{CD} 6^{-} / \mathrm{CD} 34^{+} / \mathrm{CD} 144^{+}$, and $\left.\mathrm{CD} 56^{+} / \mathrm{CD} 34^{-} / \mathrm{CD} 144^{-}\right)$were isolated from human adult muscle as myoendothelial cells, endothelial cells, and myogenic cells, respectively. When their ability of cell survival and muscle regeneration was compared by intramuscular implantation into SCID mice, $\mathrm{CD} 6^{+} / \mathrm{CD} 34^{+} / \mathrm{CD} 144^{+}$myoendothelial cells demonstrated the most significant results (Zheng et al., 2007). In a different study, CD $133^{+} / \mathrm{CD} 34^{+}$myoblasts isolated from human adult muscle showed better regeneration capacity compared to $\mathrm{CD} 33^{+} / \mathrm{CD} 4^{-}$cells following transplantation into the tibialis anterior muscles of immunodeficient mice (Negroni et al., 2009).

\section{CD45}

CD45, also known as leukocyte common antigen or protein tyrosine phosphatase receptor type $\mathrm{C}$, is a hematopoietic marker (Kaplan et al., 1990) widely used as a negative marker for SMPCs. In a number of studies, $\mathrm{CD} 45^{+}$cell depletion has already been used to enrich human SMPCs derived from adult muscle and fetal muscle (Zheng et al., 2007, 2012; Crisan et al., 2008; Lecourt et al., 2010; Okada et al., 2012; Bareja et al., 2014; Castiglioni et al., 2014; Xu et al., 2015; Garcia et al., 2018). In other studies, the absence of CD45 was used to define SMPC pools from the cell preparation derived from PSCs, adult muscle, placenta, or umbilical cord blood (Alessandri et al., 2004; Morosetti et al., 2006; Dellavalle et al., 2007; Nunes et al., 2007; Zheng et al., 2007; Proksch et al., 2009; Park et al., 2011; Awaya et al., 2012; Darabi et al., 2012; Tedesco et al., 2012; Castiglioni et al., 2014; Charville et al., 2015; Lorant et al., 2018).

\section{CD57}

CD57 is also known as beta-1,3-glucuronyltransferase 1 (B3GAT1), human natural killer 1 (HNK-1), or LEU-7. CD57 is a neuroectodermal marker expressed on natural killer cells and T-lymphocytes (Kared et al., 2016). Although knowledge about CD57 expression on SMPCs is relatively limited at this moment, a few studies reported that CD57 was useful to deplete neural cells during the purification of PSC-derived SMPCs (Borchin et al., 2013; Choi et al., 2016; Sakai-Takemura et al., 2018). When CD57 alone was used for sorting PSC-derived cells, only negative cells could differentiate into myotubes (Sakai-Takemura et al., 2018). Compared to $\mathrm{CD} 6^{-}$and $\mathrm{CD} 57^{+} / \mathrm{CD} 56^{+}$cells, $\mathrm{CD}^{-} 7^{-} / \mathrm{CD}^{+} 6^{+}$cells showed significantly increased expression of MyoD1, Myogenin, and MyHC. CD57 ${ }^{-} / \mathrm{CD}^{+} 6^{+}$cells also showed higher expression of Myogenin and Pax7 than human fetal skeletal muscle and undifferentiated human ESCs (Choi et al., 2016). In a different study, CD $57^{-} / \mathrm{CD} 56^{+}$PSC-derived SMPCs showed higher expression of Pax7, Myf5, and MyHC than unsorted cells in culture. However, there was no difference in engraftment rate between $\mathrm{CD} 57^{-} / \mathrm{CD} 56^{+}$cells and unsorted cells when intramuscularly transplanted into mdx-NSG mice (Hicks et al., 2017).

\section{CD106}

CD106 (vascular cell adhesion molecule 1) has been known to show expression in MSCs, activated endothelial cells, and macrophages (Yang et al., 2013). Although murine satellite cells express CD106 (Liu et al., 2015; Maesner et al., 2016), it seems that CD106 expression in human SMPCs remains controversial. Some studies showed that the expression of this marker was positive in adult muscle-derived SMPC populations (Sinanan et al., 2004; Lecourt et al., 2010) while other studies reported an absence of CD106 expression in different types of SMPCs derived from PSCs, adult muscle and fetal muscle (Morosetti et al., 2006; Dellavalle et al., 2007; Crisan et al., 2008; Pisani et al., 2010b; Awaya et al., 2012; Darabi et al., 2012). Further studies would be required to determine the expression of CD106 on human SMPCs.

\section{CD108}

CD108, or semaphorin 7A, is a glycophosphatidylinositol-linked glycoprotein. When CD108 was used as a sole marker for sorting iPSC-derived SMPCs, CD108 ${ }^{-}$cells showed significantly higher levels of myotube formation in vitro compared to the unsorted cells. Isolated $\mathrm{CD}^{-} 7^{-} / \mathrm{CD} 108^{-} / \mathrm{CD} 271^{+} / \mathrm{ErbB}^{+}$cells from iPSC-derived SMPCs were able to form myotubes with high efficiency in culture and when transplanted into the tibialis anterior muscles of immunodeficient dystrophin-deficient NSG-mdx ${ }^{4 \mathrm{Cv}}$ mice (Sakai-Takemura et al., 2018). In adult skeletal muscle, CD108 was expressed on both fibroblasts and myoblasts; this discrepancy is not well-understood (Sakai-Takemura et al., 2018).

\section{Combinations of Surface Markers Used for SMPC Enrichment}

To date, cell sorting by several combinations of cell surface markers has worked successfully to enrich human PSC-derived SMPCs and to deplete undesirable cell types (Table 2). Although these individual works supported the feasibility of SMPC isolation using different combinations of surface markers, one common challenge is that the procedure becomes complicated with multiple sorting steps.

\section{Which Surface Markers Would Be Promising for Human SMPC Isolation?}

Based on our comprehensive search of the literature as described above, we summarize the promising surface markers that have already been used to enrich human PSC-derived SMPCs (Table 3; the rows of these markers are highlighted in gray). We include possible markers that have confirmed expression in human PSCderived SMPCs but have not been tested yet for sorting human PSC-derived SMPCs (Table 3; the rows of these markers remain white). We also made note of whether they were used alone or in combination with other markers, and in which PSC lines the markers have been tested. Although this is not a definitive list, we consider the bolded markers in Table 3 to be highly promising for the enrichment of human PSC-derived SMPCs: CD10, CD54, CD56, CD82, CD271, ErbB3, and c-Met for positive selection; and CD24, CD57 for negative selection. Although it is difficult to propose the best combination of these markers at this moment, several combinations have successfully worked as described in the previous studies. They include CD10 ${ }^{+} / \mathrm{CD} 24^{-}$ (Wu et al., 2018), CD57 ${ }^{-} / \mathrm{CD}_{108^{-}} / \mathrm{CD} 271^{+} / \mathrm{ErbB}^{+}$(SakaiTakemura et al., 2018), CD56 ${ }^{+} / \mathrm{CD}^{+} 2^{+}$(Uezumi et al., 2016), 
TABLE 2 | Combinations of markers used to isolate human PSC-derived SMPCs and findings about their enrichment efficiency.

\begin{tabular}{|c|c|c|}
\hline Isolated fractions & PSCs & In vitro analysis \\
\hline $\mathrm{CD}_{10}+\mathrm{CD}^{-} 4^{-}$ & $\begin{array}{l}\text { Pax7/Myf5 dual } \\
\text { reporter ESCs, } \\
\text { and three } \\
\text { transgene-free } \\
\text { PSC lines }\end{array}$ & $\begin{array}{l}\text { In all four cell lines, only } \mathrm{CD} 10^{+} / \mathrm{CD} 24^{-} \text {cells exhibited myotube } \\
\text { formation. } \mathrm{CD} 10^{+} / \mathrm{CD} 24^{+} \mathrm{CD} 10^{-} / \mathrm{CD} 24^{-} \text {, and } \mathrm{CD} 10^{-} / \mathrm{CD} 24^{+} \\
\text {fractions contained non-myogenic cells and did not exhibit myotube } \\
\text { formation }\end{array}$ \\
\hline
\end{tabular}

$\mathrm{CD}^{-/} 7^{-/ C D 108^{-} / \mathrm{CD} 271^{+} / \text {iPSCs }}$ ErbB3

$\mathrm{CD} 54^{+} / \alpha 931^{+} / \mathrm{CD} 362^{+} \quad$ PSCs with Pax overexpression by doxycyclinebased

$\mathrm{CD}^{+} 6^{+} / \mathrm{CD} 82^{+}$

iPSCs

$\mathrm{CD}^{-} 7^{-} / \mathrm{CD}^{2} 6^{+}$

PSCs

PSCs
At $48 \mathrm{~h}$ after serial sorting most cells were $\mathrm{MyoD}^{+}, 30-40 \%$ were $\mathrm{Pax}^{+}$. The cells formed Myogenin ${ }^{+}$multinucleated myotubes. Pax7 was expressed in mononuclear cells between myotubes. When co-cultured with human adult myoblasts, the efficiency of myotube fusion was higher in the sorted cells compared to the unsoted ones

$100 \%$ of cells were $\mathrm{Pax}^{+}$. The isolated progenitors did not show expression of pluripotent stem cell markers (Oct3/4, Sox2 and Nanog) and were able to form multinucleated $\mathrm{MyHC}^{+}$myotubes following terminal differentiation

When compared to double-negative cells, Pax7 and MyoD expression was found exclusively in $\mathrm{CD} 56^{+} / \mathrm{CD} 82^{+}$cells. When compared to $\mathrm{CD} 56^{-} / \mathrm{CD}^{2} 2^{+}, \mathrm{CD}^{+} 6^{+} / \mathrm{CD}^{-} 2^{-}$and double-negative cells, $\mathrm{MyHC}^{+}$ myotube formation was actively promoted in $\mathrm{CD} 56^{+} / \mathrm{CD} 82^{+}$cells $98 \%$ of single $\mathrm{CD} 7^{-} / \mathrm{CD}^{2} 6^{+}$cells showed higher expression of Myogenin and Pax7 than human fetal skeletal muscle and undifferentiated ESCs. CD57- ${ }^{-} \mathrm{CD}_{6} 6^{+}$cells also expressed MyoD1, Myogenin and $\mathrm{MyHC}$ significantly higher than $\mathrm{CD}^{-} 6^{-}$cells and

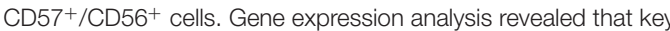
markers and transcription factors of skeletal muscle structure development were enriched in the $\mathrm{CD} 57^{-} / \mathrm{CD}_{5} 6^{+}$cell fractions CD57-/CD56 ${ }^{+}$cells could be expanded up to the hundreds of millions of cells and were easily cryo-preserved without losing myotube-forming competence

CD57-/CD56 ${ }^{+}$cells were positive with Pax7 and Myf5, specifically with $\sim 1.7$-fold more compared to unsorted preparations
In vivo analysis

References

CD10+/CD24- cells were sorted from Pax7/Myf5 dual reporter ESCs and transplanted into non-irradiated, cardiotoxin-damaged hindlimb (tibialis anterior, TA) muscles of immunodeficient dystrophin-deficient NSG-mdx ${ }^{4 C v}$ mice $\left(2.5 \times 10^{5}\right.$ cells $/ 10 \mu \mathrm{L} /$ muscle). At 4 weeks post-transplantation, $\mathrm{CD} 10^{+} / \mathrm{CD} 24^{-}$cells formed maximum of 50-60 dystrophin ${ }^{+}$and lamin $A / C^{+}$fibers, where $12 \pm 1.9 \%$ out of all lamin $\mathrm{A} / \mathrm{C}^{+}$cells were $\mathrm{Pax} 7^{+}$. CD $10^{+} / \mathrm{CD} 24^{-}$cells isolated from transgene-free PSCs were also able to form human myofibers in NSG-mdx ${ }^{4 C v}$ mice

When the sorted cells were implanted into the TA muscles of NSG-mdx ${ }^{4 C v}$ mice, 12-13 myofibers with lamin $A / C^{+}$and Spectrin ${ }^{+}$ were found on transverse muscle sections at 3 weeks of post-transplantation. $1 \times 10^{5}$ sorted cells formed more human lamin ${\mathrm{A} / \mathrm{C}^{+} \text {, spectrin }}^{+}$and dystrophin ${ }^{+}$myofibers compared to $1 \times$ $10^{6}$ unsorted cells

Sorted cells were transplanted into cardiotoxin-injured TA muscles of NSG mice $\left(5 \times 10^{5}\right.$ cells $/ 10 \mu \mathrm{L} /$ muscle). At 8 weeks and 10 months post-transplantation, $\sim 50$ and $\sim 40$ dystrophin ${ }^{+} /$lamin $\mathrm{A} \mathrm{C}^{+}$myofibers were identified in each muscle section, respectively. Cell transplantation into NSG-mdx ${ }^{4 C v}$ mice showed similar results. Lamin $\mathrm{A}^{+} \mathrm{C}^{+}$cells, which also expressed M-cadherin or Pax7, were detected in satellite cell position

The $\mathrm{CD} 57^{-} / \mathrm{CD}^{2} 6^{+}$cells were prepared from genetically corrected DMD iPSC-derived SMPCs and then transplanted into irradiated cardiotoxin-injured TA muscles of NSG-mdx ${ }^{4 \mathrm{Cv}}$ mice and immunodeficient NOD-Rag1 $1^{\text {nuil| }}$ L2r $\gamma^{\text {null }}$ (NRG) mice $(2 \times$ $10^{6}$ cells/muscle). $\sim 100$ and $\sim 380$ laminin $+/$ lamin $\mathrm{A} \mathrm{C}^{+}$myofibers per muscle section were detected in NSG-mdx ${ }^{4 C V}$ mice and NRG mice, respectively

Sorted cells were transplanted into cardiotoxin-injured TA muscles of NSG-mdx ${ }^{4 C r}$ mice $\left(2 \times 10^{6}\right.$ cells/10 $\mu \mathrm{L} /$ muscle). CD57-/CD56 ${ }^{+}$cells did not show improved engraftment rate compared to unsorted cells. Significant differences were not found in spectrin ${ }^{+} / \mathrm{lamin} \mathrm{A} / \mathrm{C}^{+}$and dystrophin ${ }^{+}$myofibers generated by both groups of cells
Jezumi et al., 2016

Wu et al., 2018

Sakai-Takemura et al., 2018

Magli et al., 2017

Choi et al., 2016

Hicks et al., 201 
TABLE 2 | Continued

Isolated fractions In vitro analysis

In vivo analysis

References

${\mathrm{CD} 271^{+} / \mathrm{ErbB}^{+}}^{+} \quad \mathrm{PSCs} \quad \mathrm{CD} 271^{+} /$ErbB3 $^{+}$expressed Pax7 and Myf5 20-fold more than
double-negative cells. CD271+/ErbB3 ${ }^{+}$cells showed significantly higher myotube formation compared to CD271+/ErbB3- ${ }^{-}$. CD271-/ErbB3 ${ }^{+}$and double-negative cells

At Day 5 and Day 15 in myogenic differentiation medium, CD271+/ErbB3 ${ }^{+}, \mathrm{CD} 271^{+} / \mathrm{ErbB}^{-}$, and CD271-/ErbB3 ${ }^{+}$cells were evaluated with reporter protein expression (tdTomato driven by Pax7 promotor and EGFP by Myf5 promotor). At both timepoints, EGFP-positive myogenic cells were equally distributed in three fractions. When these fractions were plated and subjected to terminal differentiation, all of three fractions from Day 5 could not differentiate into myotubes. In contrast, all three fractions from Day 15 contained mixed populations of $\mathrm{MyHC}^{+}$myotubes and $\mathrm{MyHC}^{-}$non-myogenic cells

$60-80 \%$ of $\mathrm{CD} 73^{+} / \mathrm{CD} 56$ cells were $\mathrm{MyoD}^{+}$. Cells adopted a bipolar cell morphology at $24 \mathrm{~h}$ expression of Myogenin, desmin, actin and MyHC were confirmed. These differentiated myotubes were capable of spontaneous twitching in culture

Cell sorting was performed at three time points (Day 23, 25, and 35) following directed myogenic differentiation of PSCs. At Day 23, sorted cells expressed Six4 and Pax3. At Day 25, sorted cells expressed Pax7. At Day 35, sorted cells were $98 \% \mathrm{Pax}^{+}$and $96 \% \mathrm{Pax}^{+}$. The cells sorted at Day 35 demonstrated progressive terminal muscle differentiation when plated down, as shown by expression of Myf5, Myogenin, and MyHC. After 3 days of terminal differentiation, all cells expressed MYF5 and few retained Pax7 expression. After 9 days, myotubes were formed while most cells were Myogenin ${ }^{+}$and $\mathrm{MyHC}^{+}$

DMD iPSC were genetically corrected by CRIPSR/Cas9 method and prepared SMPCs. CD271 ${ }^{+}$cells and ErbB3 ${ }^{+}$cells were sorted from these SMPCs and transplanted into cardiotoxin-injured TA muscles of NSG-mdx ${ }^{4 C v}$ mice $\left(2 \times 10^{6}\right.$ cells $/ 10 \mu \mathrm{L} /$ muscle). Both cell types showed significantly higher engraftment rate than $\mathrm{CD}^{+} 6^{+}$and unsorted cells, as determined by the number of myofibers with human lamin $\mathrm{A}^{+} \mathrm{C}^{+} /$spectrin $^{+} /$dystrophin ${ }^{+}$. Engraftment of ErbB3 ${ }^{+}$cells could restore dystrophin expression up to the levels observed in the muscles implanted freshly isolated human fetal myocytes

CD271 $1^{+} / \mathrm{ErbB}^{+}$cells were isolated from Pax7/Myf5 dual reporter ESCs and transplanted into non-irradiated, cardiotoxin-damaged TA muscles of NSG-mdx ${ }^{4 \mathrm{Cr}}$ mice $\left(2.5 \times 10^{5}\right.$ cells/10 $\mu \mathrm{L} /$ muscle). At 4 weeks post-transplantation, CD271+/ErbB3 ${ }^{+}$cells were able to form maximum of 10-15 dystrophin ${ }^{+}$and lamin $\mathrm{A} / \mathrm{C}^{+}$myofibers per section but no Pax $7^{+}$cells were detected

Before transplantation, $\mathrm{CD}_{3} 3^{+} / \mathrm{CD} 6^{+}$-sorted cells were transduced with a lentiviral vector carrying a triple reporter construct expressing herpes simplex virus thymidine kinase, enhanced GFP, and luciferase. The cells were then transplanted into the cardiotoxin-injured TA muscles of immunodeficient SCID/Beige mice $\left(5 \times 10^{5}\right.$ cells/muscle). Stable bioluminescence signals were confirmed even after 6 months of cell transplantation. Immunohistochemical analyses of implanted muscles demonstrated that an average of $7 \%$ of muscle fibers was positive with human laminin 


\begin{tabular}{lcl}
\hline Marker & + /- selection & Strength \\
\hline CD10 & + & - Enriched SMPC population from transgene-free PSCs
\end{tabular}

- Enriched SMPC population from transgene-free PSCs and Pax7/Myf5 reporter ESCs when used in

combination with CD24- selection (Wu et al., 2018)

- Exclusion of $\mathrm{CD} 11 \mathrm{~b}^{+}$cells efficiently depleted hematopoietic cells among SMPC population derived from fetal muscle, when used in combination with GlyA- /CD45- selection (Castiglioni et al., 2014), and from adult muscle when used in combination with CD45- selection (Bareja et al., 2014)

CD13 - Expression was detected on 40-64\% human

Pax7-overexpressing PSC-derived SMPCs (Darabi et al., 2012) and iPSC-derived mesoangioblast-like stem/progenitor cells (Tedesco et al., 2012)

- Presence or absence of expression could distinguish $\mathrm{CD}^{+} 6^{+}$adult muscle-derived myogenic cells with or without adipogenic capabilities, respectively (Lecourt et al., 2010; Pisani et al., 2010a; Agley et al., 2013)

CD24

- Enriched SMPC population from transgene-free PSCs and Pax7/Myf5 reporter ESCs when used in combination with $\mathrm{CD} 10^{+}$selection (Wu et al., 2018)

- CD29/Integrin alpha-9 dimer ( $\alpha 931$ ) efficiently isolated SMPC population from Pax7-overexpressing PSCs (Magli et al., 2017)

- Expression confirmed by $>70 \%$ cells of PSC-derived SMPC populations (Awaya et al., 2012; Darabi et al. 2012; Abujarour et al., 2014; Magli et al., 2017 Sakai-Takemura et al., 2018)

- Enriched SMPC population from adult muscle when used in combination with CD31-/CD34- $/$ CD $^{-} 5^{-} /$EGFR $^{+}$selection (Charville et al., 2015), and with CD56 $/$ CD31-/CD45selection (Xu et al., 2015), as well as from fetal muscle when used in combination with

CD56 + /CD184+/CD31-/CD34-/CD45- selection (Garcia et al., 2018)

CD31 - $\quad-$ Exclusion of $\mathrm{CD} 31^{+}$cells in a series of sequential isolation steps efficiently depleted endothelial cells among SMPC population derived from adult muscle (Bareja et al., 2014; Xu et al., 2015; Garcia et al., 2018) and fetal muscle (Cerletti et al., 2006; Castiglion et al., 2014)
- Efficiency as a sole marker is unknown

- Efficiency when used with markers other than CD24is unknown

- May be redundant as a negative marker, as the expression on human PSC-derived SMPCs was rarely reported

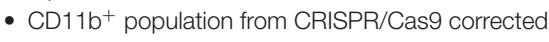
DMD iPSC-derived SMPC was able to form myotube in culture (Hicks et al., 2017)

- Never used to isolate human PSC-derived SMPCs, efficiency is unknown whether as a sole marker or in combination

- May be redundant as a negative marker, as CD15 expression on human PSC-derived SMPCs has not been confirmed yet

- Efficiency as a sole marker is unknown

- Efficiency when used with markers other than $\mathrm{CD} 0^{+}$ is unknown

- Never used alone (as opposed to $\alpha 9 \beta 1$ dimer) to isolate human PSC-derived SMPCs; efficiency is unknown whether as a sole marker or in combination

- A population of $\mathrm{CD} 56^{+} / \mathrm{CD} 29^{+}$cells without Pax7 expression was identified in healthy adult human skeletal muscle, implying that CD29 expression is not exclusive to satellite cells (Xu et al., 2015)

- May be redundant as a negative marker for PSC-derived SMPCs as expression was not detected on human Pax7-overexpressing PSC-derived SMPCs (Darabi et al., 2012) and iPSC-derived mesoangioblast-like stem/progenitor cells (Tedesco et al., 2012)

- CD31 expression itself does not correspond to SMPC properties, as both $\mathrm{CD} 146^{+} / \mathrm{CD} 31^{+}$and

CD146 ${ }^{+} / \mathrm{CD} 31^{-}$cells isolated from human fetal muscle and cultured were able to differentiate into myotubes (Cerletti et al., 2006)
- Detected on $\sim 97 \%$ human primary myoblasts (Wu et al., 2018)

- Detected on $\sim 80 \% \mathrm{Pax} 7^{+}$cells derived from adult muscle (Wu et al., 2018)

- Detected on 97\% human adult pericytes (Dellavalle et al., 2007)

- Detected on $38.4 \%$ mononucleated cells derived from fetal muscle (Castiglioni et al., 2014)

- Not detected on human primary myoblasts (Wu et al., 2018)

- Detected on $90.4 \%$ mononucleated cells derived from fetal muscle (Castiglioni et al., 2014)

- Co-expression with CD56 was detected on $100 \%$ $\mathrm{Pax} 7^{+}$satellite cells in healthy adult skeletal muscle (Xu et al., 2015)

- Detected on SMPCs derived from postnatal muscle (Garcia et al., 2018) and adult muscle (Lecourt et al., 2010: Woodard et al., 2014; Charville et al., 2015; Xu et al., 2015; Lorant et al., 2018)

- Expression on SMPCs derived from adult muscle had been reported to be both detectable (Hollemann et at. 2008; Lecourt et al., 2010; Bareja et al., 2014; Xu et al., 2015) and undetectable (Alessandri et al., 2004; Dellavalle et al., 2007; Charville et al., 2015; Lorant et al., 2018)

(Continued) 


\section{Marker \\ $+/-$ selectio}

$\mathrm{CD} 34$

Strength

- CD34- MDSCs displayed high expression of

myogenic markers and exhibited consistent myogenic potential regardless of preparation and culture period (Pisani et al., 2010b)

- CD34- MDSCs retained higher expression of CD56 in culture when sorted along with both $\mathrm{CD} 90^{+}$and CD90- selections (Proksch et al., 2009), CD133 ${ }^{+}$ selection (Negroni et al., 2009), as well as $\mathrm{CD}^{+}{ }^{+} / \mathrm{CD} 144^{-}$selection (Okada et al., 2012)

- Exclusion of CD45+ cells in a series of sequentia isolation steps efficiently depleted hematopoietic cells among SMPC population derived from adult muscle (Zheng et al., 2007, 2012; Lecourt et al., 2010; Okada et al., 2012; Bareja et al., 2014; Xu et al., 2015) and fetal muscle (Crisan et al., 2008; Castiglioni et al. 2014; Garcia et al., 2018)

CD54 - $\quad+\quad$ Enriched SMPC population from Pax7-overexpressing PSCs when used alongside with CD362+/integrin a9 $\beta 1^{+}$selection (Magli et al., 2017)

- Able to act as a sole marker to isolate SMPC population from Pax7-overexpressing PSCs (Magli et al., 2017)

- Enriched SMPCs from transgene-free ESC-derived MSCs when used alongside $\mathrm{CD} 73^{+}$selection (Barberi et al., 2007)

- Enriched transgene-free iPSC-derived SMPCs when used alongside CD82+ ${ }^{+}$selection (Uezumi et al., 2016) - Enriched transgene-free PSC-derived SMPCs when used alongside CD57- selection (Hicks et al., 2017)

- Enriched SMPC population derived from fetal muscle (Crisan et al., 2008; Castiglioni et al., 2014) and adult muscle (Dellavalle et al., 2007: Zheng et al., 2007,

2012; Lecourt et al., 2010; Pisani et al., 2010a; Okada et al., 2012; Bareja et al., 2014; Woodard et al., 2014 Xu et al., 2015; Alexander et al., 2016; Choi et al. 2016) alongside other markers

- Able to act as a sole marker to isolate SMPC population derived from adult muscle (Sinanan et al., 2004; Lecourt et al., 2010; Pisani et al., 2010a; Lorant et al., 2018)
Weakness

- May be redundant as a negative marker for PSC-derived SMPCs as expression was reported to be non-existent or low on human PSC-derived SMPCs (Awaya et al., 2012; Darabi et al., 2012; Hwang et al., 2014)

- May be redundant as a negative marker for PSC-derived SMPCs as expression was not detected on human Pax7-overexpressing PSC-derived SMPCs (Darabi et al., 2012) and iPSC-derived mesoangioblast-like stem/progenitor cells (Tedesco et al., 2012)

- Efficiency to isolate transgene-free PSC-derived SMPCs is unknown

- Efficiency to isolate transgene-based PSC-derived SMPCs is unknown

- Efficiency as a sole marker to isolate PSC-derived SMPCs is unknown

- May not improve SMPC purity by much as almost all cells in some PSC-derived SMPC populations express CD56: 98-100\% of human Pax7-overexpressing PSC-derived SMPCs (Darabi et al., 2012), 95.3\% of $\mathrm{Pax}^{+}$or $\mathrm{Pax} 7^{+}$cells from ESC-derived SMPCs

(Awaya et al., 2012), 75\% MyoD-overexpressing ESCs (Goudenege et al., 2012)

- SMPCs may also reside in CD56- population, as evidenced by several $\mathrm{CD}^{-} 6^{-}$populations that were able to form myotubes both in vitro and in vivo: a population of "endothelial cells"

(CD45-/CD56- $/ \mathrm{CD}^{-} 4^{+} / \mathrm{CD} 144^{+}$selection) isolated from adult muscle (Okada et al., 2012), a population of "perivascular stem cells"



from adult muscle (Zheng et al., 2012), and a

population of "perivascular cells"

(CD146+/CD34-/CD45-/CD56- selection) isolated from multiple human organs and placenta (Crisan et al., 2008; Park et al., 2011); the latter two

populations showed upregulated CD56 expression

after expression in culture
Expression level in SMPCs from other sources

- Some groups of SMPCs have been confirmed as CD34- populations: proliferative satellite cells (CD34 ${ }^{-} / \mathrm{CD}^{-} 6^{+} / \mathrm{Myf5}^{+}$cells), and a minority of pericytes and mesoangioblasts with adipogenic potential (CD34- ${ }^{-}$CD56- $^{-}$cells) (Péault et al., 2007).

- Expression reported to be in varied levels on SMPCs from different sources (see section CD34)

- Not detected on SMPC populations derived from adult muscle, placenta, and umbilical cord blood (see section CD45)

- Expression on cultured human skeletal muscle cells can be induced with various cytokine treatments (Goebels et al., 1992; Michaelis et al., 1993; Bartoccioni et al., 1994; Marino et al., 2001)

- Detected on $>80 \%$ satellite cells derived from adult muscle (Negroni et al., 2009)

- Detected on $83 \%$ "slowly adhering cell" fraction of culture derived from adult muscle (Okada et al., 2012)

- Detected on $77.1 \% \mathrm{CD}^{4} 5^{-}$cultured cells derived from adult muscle (Zheng et al., 2012)

- Detected on 69-99\% SMPCs derived from adult muscle (Lorant et al., 2018)

- Detected on SMPCs derived from PSCs, postnata muscle, adult muscle, fetal muscle, and placenta (see section CD56) 
CD57 - - Exclusion of $\mathrm{CD} 57^{+}$cells in a series of sequential isolation steps efficiently depleted neural cells among transgene-free PSC-derived SMPC population (Borchin et al., 2013; Hicks et al., 2017 Sakai-Takemura et al., 2018) and Mesogenin1/eGFP reporter human ESC-derived SMPC population (Cho et al., 2016)

- Able to enrich transgene-free iPSC-derived SMPCs when used as a sole marker in a single-step negative selection (Sakai-Takemura et al., 2018)

CD73 + - The expression was confirmed in $99.4 \% \mathrm{Pax}^{+}$or Pax $7^{+}$cells from ESC-derived SMPCs (Awaya et al., 2012), 96.8\% MyoD-overexpressing ESCs (Goudenege et al., 2012) and 66\% SMPCs derived from adult muscle (Woodard et al., 2014)

CD82 + - Enriched transgene-free iPSC-derived SMPCs (Uezumi et al., 2016) and SMPCs derived from adult muscle (Alexander et al., 2016) when used alongside CD56+ selection

- Enriched SMPCs derived from fetal muscle when used alongside CD146 ${ }^{+}$selection (Alexander et al., 2016)

- Can be used alone to enrich SMPCs derived from adult muscle (Uezumi et al., 2016)

CD108 _ _ _ Enriched transgene-free iPSC-derived SMPCs as a sole marker and when used alongside CD57-/CD271+/ErbB3+ selection (Sakai-Takemura et al., 2018)

- Expression confirmed in PSC-derived SMPCs (Darabi et al., 2012; Tedesco et al., 2012; Sakai-Takemura et al., 2018)

- Enriched SMPC population derived from fetal muscle (Cerletti et al., 2006; Crisan et al., 2008; Lapan et al., 2012; Alexander et al., 2016), adult muscle (Zheng et al., 2012) and placenta (Park et al., 2011)

CD184 + Enriched highly pure SMPCs from transgene-free PSC-derived populations when used in combination with CD57-/AChR ${ }^{-} / \mathrm{C}^{-} \mathrm{Met}^{+}$selection (Borchin et al., 2013)
- May be redundant as a negative marker as expression

on human PSC-derived SMPCs was rarely reported

- May not improve SMPC purity by much if expression level is low in PSC-derived SMPC populations

- Never used to isolate SMPCs from any source, efficiency is unknown whether as a sole marker or in combination

- Efficiency to isolate transgene-based PSC-derived SMPCs is unknow

- Efficiency as a sole marker to isolate PSC-derived SMPCs is unknown

- Fairly new marker, expression level in PSC-derived SMPCs have not been reported much, therefore hard to gauge redundancy of isolation based on this marker

- Efficiency to isolate transgene-based PSC-derived SMPCs is unknown

- Efficiency as a sole marker or when used with markers other than $\mathrm{CD}^{-} 7^{-} / \mathrm{CD} 271^{+} / \mathrm{ErbB}^{+}$is unknown

- Expression level in PSC-derived SMPCs is rarely reported, therefore hard to gauge redundancy of isolation based on this marker

- Efficiency to isolate PSC-derived SMPCs is unknown

- May not improve SMPC purity by much if very highly expressed in PSC-derived SMPC populations; for example, $100 \%$ of human Pax7-overexpressing PSC-derived SMPCs were CD146+ (Darabi et al., 2012)

- Does not exclusively select SMPCs. Also expressed on neural cells, therefore most likely only reliable when used alongside c-Met: highly pure SMPCs were found

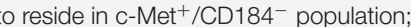

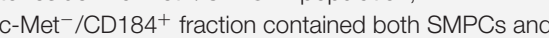
neural cells; C-Met ${ }^{-} / \mathrm{CD} 184^{-}$fraction did not have any SMPCs (Borchin et al., 2013)

- Efficiency when used with markers other than c-Met is unknown
- Detected on SMPCs derived from fetal muscle (Crisan et al., 2008) and adult muscle (Lecourt et al, 2010; Uezumi et al., 2016; Lorant et al., 2018)

- Detected on $\sim 97 \% \mathrm{Pax}^{+}$or M-cadherin+ satellite cells (Uezumi et al., 2016)

- Detected on both fibroblasts and myoblasts in adult skeletal muscle (Sakai-Takemura et al., 2018)

- Detected on $41.11 \%$ culture-expanded pericytes derived from adult muscle (Dellavalle et al., 2007)

- Detected on $66.9 \% \mathrm{CD}^{-} 5^{-}$cultured cells derived from adult muscle (Zheng et al., 2012)

- Detected on $35-80 \%$ mononucleated cells derived from fetal muscle (Lapan et al., 2012)

- Detected on $63.2 \%$ mononucleated cells derived from fetal muscle (Castiglioni et al., 2014)

- Detected on SMPCs derived from adult muscle (Bareja et al., 2014; Marg et al., 2014; Garcia et al., 2018) 

- Detected on 95\% CD54+/integrin proliferating SMPCs

nriched highly pure nd other non-myogenic cell types from (B)

Markers with gray background have already been used to isolate human PSC-derived SMPCs. The markers with white background are the ones that have not been
SMPC isolation. Based on our literature search, we propose that the bolded markers would be highly promising for SMPC isolation from human pluripotent sources. 
$\mathrm{CD} 21^{+} / \mathrm{ErbB}^{+}$(Hicks et al., 2017), CD57-/CD56 ${ }^{+}$(Choi et al., 2016; Hicks et al., 2017), and $\mathrm{CD}^{-} 7^{-} / \mathrm{AChR}^{-} / \mathrm{CD} 184^{+} / \mathrm{c}^{-}$ $\mathrm{Met}^{+}$(Borchin et al., 2013; Table 2). To further improve the efficiency of SMPC enrichment, additional studies would be necessary to test different combinations.

\section{REMAINING CHALLENGES TO ISOLATE HUMAN SMPCS FROM PLURIPOTENT STEM CELLS}

The current knowledge of cell surface markers supports our ability to isolate and characterize PSC-derived SMPCs. While a number of positive and negative markers are potentially available to define SMPC pools, it may still not be easy to prepare a pure population of SMPCs from PSC-derived cells.

In recent years, several culture protocols have been developed to derive skeletal myocytes from human PSCs. Transgene-based SMPC derivation uses the overexpression of myogenic genes, such as PAX7 (Darabi et al., 2012; Skoglund et al., 2014) and MYOD1 (Tanaka et al., 2013; Abujarour et al., 2014; Yasuno et al., 2014; Maffioletti et al., 2015). Although transgene-based approaches yield SMPCs with high efficiency, the resulting cells may not fully reflect the natural endogenous processes of SMPC proliferation, differentiation, and maturation, because such overexpression requires genetic modification (reviewed in Jiwlawat et al., 2018). Similarly, although fluorophore-labeled SMPCs warrant convenient isolation, the insertion of transgene constructs that link fluorophore reporter genes to myogenic genes present the same concerns associated with transgenebased approaches. As such, transgene-free methods may be more suitable to prepare SMPCs for clinical applications, because these methods only use defined culture conditions supplemented with factors that encourage myogenic lineage commitment. However, the efficiency of SMPC derivation is relatively lower in the existing transgene-free methods compared to transgenebased approaches. Further, transgene-free SMPC derivation gives rise to a heterogeneous cell population with an embryonic or perinatal phenotype which contains myocytes of various stages and other cell types (Jiwlawat et al., 2017). As such, to obtain SMPC populations with high quality and quantity, cell sorting using cell surface markers would be required. A better understanding of SMPC surface markers is crucial to improve the purity of resulting cell populations.

With the use of specific antibodies targeting only cells expressing a particular surface marker, positive selection yields a higher purity of the desired population. However, positively selected cells may retain antibodies and other labeling agents, which may interfere with downstream culture and assays. Negatively selected cells would not carry such concern, but it is less efficient in terms of purity to deplete all undesired cells by only relying on negative selection. Positive selection and negative selection can be used to purify a cell population sequentially through several cycles of the procedure.

When designing a strategy of SMPC enrichment, we should consider the expression level of each surface marker in unsorted populations. Intuitively, CD29 and CD56 are well-established surface markers that have been used for SMPC enrichment in various cell lines. However, if an SMPC surface marker is already very highly expressed in pre-sorted populations (>90\%), it may be redundant to enrich using this surface marker, as the purity may not improve by much. The same applies to negative SMPC surface markers that are already minimally expressed in unsorted populations. A surface marker barely expressed in the unsorted population may play an important biological role but would not be useful as a target for live cell isolation. Similarly, if a surface marker is also highly expressed on non-SMPC cell types, it would no longer serve to distinguish SMPC identity from the background cell populations.

We also need to carefully compare the rate of improvement in muscle differentiation efficiency between the unsorted and sorted populations. When quantifying the success rate of SMPC enrichment, the in vivo capacity of muscle regeneration should be taken into consideration alongside the ability of the cells to differentiate into muscle in vitro. Forming new muscle fibers, repopulating the satellite cell niche, and vascularization of the affected area are all crucial to establish the structural integrity and functionality of the regenerated muscle tissue. It is possible that unsorted SMPC populations may perform better after transplantation, as these more heterogenous unsorted populations could contain cells that play a supporting role for muscle repair and regeneration. "Enriched" SMPC populations may show an increased rate of myotube formation in vitro where conditions are strictly controlled. However, these cells may engraft more poorly than unsorted populations due to the absence of non-SMPC support cells. Therefore, the purpose of SMPC enrichment should be considered when selecting surface markers, as the resulting cell population most ideal for in vitro modeling may not also be the most ideal for transplantation studies.

Our literature search further verifies that a surface marker profile cannot be assumed to be similar for all SMPC lines. A surface marker could enrich SMPCs from one cell line very well only to be rendered useless in another cell line. For example, CD271 and ErbB3 efficiently enriched SMPCs derived via both transgene-free and transgene-based methods from several PSC lines (Hicks et al., 2017; Sakai-Takemura et al., 2018). However in a different paper, when a combination of CD271 and Erb3 was used for an ESC line (Pax7/Myf5 reporter ESC), the similar efficiency of SMPC enrichment could not be replicated (Wu et al., 2018). Thus, more comprehensive isolation strategies that account for expression-level variability are warranted. The variance in antibody binding affinity from different suppliers should also be carefully considered when designing an antibodybased isolation strategy as well as in data interpretation.

When differentiating skeletal myocytes from human PSCs, there has been inconsistency between studies with regards to evaluating differentiation efficiency and myocyte maturity (reviewed in Jiwlawat et al., 2018). It would be greatly beneficial in the field to establish standards for these evaluations in order to make better comparisons across protocols. To achieve this goal, cell characterization using specific surface markers against PSC-derived SMPCs would be crucial. Another challenge in the field is that cultured skeletal myocytes often retain an embryonic 
or perinatal phenotype. While better establishment of culture technique would be required to obtain SMPCs and myocytes with sufficient quality, it would also be worthwhile to define stagespecific markers to distinguish embryonic, perinatal, and adult phenotypes of SMPCs and myoblasts.

To date, a majority of SMPC surface markers were profiled based on the knowledge from satellite cells, resident SMPCs located between the basal lamina and sarcolemma of adult muscle fibers. Even though these possible markers can be used to sort SMPCs into subpopulations, it remains uncertain whether these subpopulations are homogeneous in their function and lineage commitment. Moreover, given the fact that satellite cells from different in situ locations within the same donor can have distinct molecular signatures (Harel et al., 2009; Sambasivan et al., 2009), these markers should not be utilized alone to unequivocally identify SMPCs, especially "de novo SMPCs" derived from PSCs. Additionally, contradictory reports on marker expression on SMPCs imply that different culture conditions may lead to the heterogeneity of SMPCs. Different culture media and durations would influence the expression of specific markers in timepointand sample-dependent manners. Ultimately, it would be more helpful if a sole marker was available to specifically enrich only SMPCs. For other stem cell types such as HSCs and MSCs, cell surface markers are already well-characterized and defined for identification. In contrast, our knowledge in the field of myogenic progenitors is still developing. To advance, additional studies are needed to discover specific markers that can be used alone to detect a pure population of SMPCs.

Lastly, another concern is that throughout the reports there is inconsistency on how to evaluate the myogenic potential in sorted cell pools. Some studies examined commitment to the myogenic lineage based on a pooled expression of common muscle cell markers, whereas several other studies only identified the expression of one marker. When comparing in vivo regenerative capacity using intramuscular transplantation, the results may also vary depending on the animal models used, how muscle injury was induced, the number of cells transplanted, the duration between transplantation and analysis, and the position in muscle used for section preparation and analysis.

\section{REFERENCES}

Abujarour, R., Bennett, M., Valamehr, B., Lee, T. T., Robinson, M., Robbins, D., et al. (2014). Myogenic differentiation of muscular dystrophy-specific induced pluripotent stem cells for use in drug discovery. Stem Cells Transl. Med. 3, 149-160. doi: 10.5966/sctm.2013-0095

Agley, C. C., Rowlerson, A. M., Velloso, C. P., Lazarus, N. R., and Harridge, S. D. R. (2013). Human skeletal muscle fibroblasts, but not myogenic cells, readily undergo adipogenic differentiation. J. Cell Sci. 126, 5610-5625. doi: $10.1242 /$ jcs. 132563

Albini, S., Coutinho, P., Malecova, B., Giordani, L., Savchenko, A., Forcales, S., et al. (2013). Epigenetic reprogramming of human ES cells into skeletal muscle cells and generation of contractile myospheres. Cell Rep. 3, 661-670. doi: 10.1016/j.celrep.2013.02.012

Alessandri, G., Pagano, S., Bez, A., Benetti, A., Pozzi, S., Iannolo, G., et al. (2004). Isolation and culture of human muscle-derived stem cells able to differentiate into myogenic and neurogenic cell lineages. Lancet 364, 1872-1883. doi: 10.1016/S0140-6736(04)17443-6
Furthermore, calculation of myotube formation efficiency may differ based on the usage of immunohistochemical staining, the counting of positive cells in a field of view, the number of nuclei per myotube, and the percentage of nuclei within myotubes. Since the ability to generate fully matured myotubes is pivotal for transplanted SMPCs to have clinical significance, a comprehensive analysis of the anatomical features, physiological functionality and fiber type expressed should be performed to gauge the state of myotube maturity.

\section{CONCLUDING REMARKS}

Recent studies have offered valuable knowledge regarding cell surface markers to identify SMPCs. While promising positive and negative markers have been identified using different SMPC types, it remains challenging to use them for sorting human PSCderived SMPCs in efficient ways. Furthermore, there is still a need to standardize methods of quantifying SMPC properties in order to facilitate comparisons between surface marker expressions. This would allow for precise utilization of SMPC surface markers to enhance the enrichment and differentiation of SMPCs. Having control over the composition of SMPC populations could lead to new state of the art uses for disease modeling, drug testing, and therapeutic development.

\section{AUTHOR CONTRIBUTIONS}

S-RT designed the outline of manuscript, performed manuscript search, and primarily prepared the manuscript. SR and EL provided critical suggestions about the contents and edited the manuscript. MS proposed conception and design of the manuscript and wrote the manuscript. All authors approved the final version of the manuscript.

\section{FUNDING}

This work was supported by grants from NIH/NINDS (R01NS091540, MS), the ALS Association (15-IIP-201, MS), and the University of Wisconsin Foundation (MS and S-RT).

Alexander, M. S., Rozkalne, A., Colletta, A., Spinazzola, J. M., Johnson, S., Rahimov, F., et al. (2016). CD82 is a marker for prospective isolation of human muscle satellite cells and is linked to muscular dystrophies. Cell Stem Cell 19, 800-807. doi: 10.1016/j.stem.2016.08.006

Álvarez-Viejo, M., Menéndez-Menéndez, Y., and Otero-Hernández, J. (2015). CD271 as a marker to identify mesenchymal stem cells from diverse sources before culture. World J. Stem Cells 7, 470-476. doi: 10.4252/wjsc.v7.i2.470

Anastasi, G., Cutroneo, G., Santoro, G., Arco, A., Rizzo, G., Bramanti, P., et al. (2008). Costameric proteins in human skeletal muscle during muscular inactivity. J. Anat. 213, 284-295. doi: 10.1111/j.1469-7580.2008. 00921.x

Anastasi, G., Cutroneo, G., Trimarchi, F., Santoro, G., Bruschetta, D., Bramanti, P., et al. (2004). Evaluation of sarcoglycans, vinculin-talin-integrin system and filamin2 in alpha- and gamma-sarcoglycanopathy: an immunohistochemical study. Int. J. Mol. Med. 14, 989-999. doi: 10.3892/ijmm.14.6.989

Armulik, A., Genove, G., and Betsholtz, C. (2011). Pericytes: developmental, physiological, and pathological perspectives, problems, and promises. Dev. Cell 21, 193-215. doi: 10.1016/j.devcel.2011.07.001 
Asahara,. T., and Kawamoto, A. (2004). Endothelial progenitor cells for postnatal vasculogenesis. Am. J. Physiol. Cell Physiol. 287, C572-C579. doi: 10.1152/ajpcell.00330.2003

Asakura, A., Seale, P., Girgis-Gabardo, A., and Rudnicki, M. A. (2002). Myogenic specification of side population cells in skeletal muscle. J. Cell Biol. 159, 123-134. doi: 10.1083/jcb.200202092

Awaya, T., Kato, T., Mizuno, Y., Chang, H., Niwa, A., Umeda, K., et al. (2012). Selective development of myogenic mesenchymal cells from human embryonic and induced pluripotent stem cells. PLoS ONE 7:e51638. doi: 10.1371/journal.pone.0051638

Bachrach, E., Perez, A. L., Choi, Y., Illigens, B. M. W., Jun, S. J., Del Nido, P., et al. (2006). Muscle engraftment of myogenic progenitor cells following intraarterial transplantation. Muscle Nerve 34, 44-52. doi: 10.1002/mus.20560

Bajek, A., Porowinska, D., Kloskowski, T., Brzoska, E., Ciemerych, M. A., and Drewa, T. (2015). Cell therapy in Duchenne muscular dystrophy treatment: clinical trials overview. Crit. Rev. Eukaryot. Gene Expr. 25, 1-11. doi: 10.1615/CritRevEukaryotGeneExpr.2015011074

Barberi, T., Bradbury, M., Dincer, Z., Panagiotakos, G., Socci, N. D., and Studer, L. (2007). Derivation of engraftable skeletal myoblasts from human embryonic stem cells. Nat. Med. 13, 642-648. doi: 10.1038/nm1533

Barberi, T., Willis, L. M., Socci, N. D., and Studer, L. (2005). Derivation of multipotent mesenchymal precursors from human embryonic stem cells. PLoS Med. 2:e161. doi: 10.1371/journal.pmed.0020161

Bareja, A., Holt, J. A., Luo, G., Chang, C., Lin, J., Hinken, A. C., et al. (2014). Human and mouse skeletal muscle stem cells: convergent and divergent mechanisms of myogenesis. PLoS ONE 9:e90398. doi: 10.1371/journal.pone.0090398

Bartoccioni, E., Gallucci, S., Scuderi, F., Ricci, E., Servidei, S., Broccolini, A., et al. (1994). MHC class I, MHC class II and intercellular adhesion molecule1 (ICAM-1) expression in inflammatory myopathies. Clin. Exp. Immunol. 95, 166-172. doi: 10.1111/j.1365-2249.1994.tb06032.x

Bischoff, R., and Heintz, C. (1994). Enhancement of skeletal muscle regeneration. Develop. Dyn. 201, 41-54. doi: 10.1002/aja.1002010105

Bladt, F., Riethmacher, D., Isenmann, S., Aguzzi, A., and Birchmeier, C. (1995). Essential role for the c-Met receptor in the migration of myogenic precursor cells into the limb bud. Nature 376, 768-771. doi: 10.1038/376768a0

Blanpain, C., Lowry, W. E., Geoghegan, A., Polak, L., and Fuchs, E. (2004). Selfrenewal, multipotency, and the existence of two cell populations within an epithelial stem cell niche. Cell 118, 635-648. doi: 10.1016/j.cell.2004.08.012

Borchin, B., Chen, J., and Barberi, T. (2013). Derivation and FACSmediated purification of $\mathrm{PAX} 3+/ \mathrm{PAX} 7+$ skeletal muscle precursors from human pluripotent stem cells. Stem Cell Reports 1, 620 - 631. doi: 10.1016/j.stemcr.2013.10.007

Buckingham, M. (2006). Myogenic progenitor cells and skeletal myogenesis in vertebrates. Curr. Opin. Genet. Dev. 16, 525-532. doi: 10.1016/j.gde.2006.08.008

Buhring, H. J., Kuci, S., Conze, T., Rathke, G., Bartolovic, K., Grunebach, F., et al. (2004). CDCP1 identifies a broad spectrum of normal and malignant stem/progenitor cell subsets of hematopoietic and nonhematopoietic origin. Stem Cells 22, 334-343. doi: 10.1634/stemcells.22-3-334

Cao, B., Zheng, B., Jankowski, R. J., Kimura, S., Ikezawa, M., Deasy, B., et al. (2003). Muscle stem cells differentiate into haematopoietic lineages but retain myogenic potential. Nat. Cell Biol. 5:640-646. doi: 10.1038/ncb1008

Cao, M., Gao, J., Zhou, H., Huang, J., You, A., Guo, Z., et al. (2015). HIF-2alpha regulates $\mathrm{CDCP} 1$ to promote PKCdelta-mediated migration in hepatocellular carcinoma. Tumour Biol. 37, 1651-1662. doi: 10.1007/s13277-015-3527-7

Cappellari, O., and Cossu, G. (2013). Pericytes in development and pathology of skeletal muscle. Circ. Res. 113:341-347. doi: 10.1161/CIRCRESAHA.113.300203

Caron, L., Kher, D., Lee, K. L., McKernan, R., Dumevska, B., Hidalgo, A., et al. (2016). A human pluripotent stem cell model of facioscapulohumeral muscular dystrophy-affected skeletal muscles. Stem Cells Transl. Med. 5, 1145-1161. doi: $10.5966 / \mathrm{sctm} .2015-0224$

Castiglioni, A., Hettmer, S., Lynes, M. D., Rao, T. N., Tchessalova, D., Sinha, I., et al. (2014). Isolation of progenitors that exhibit myogenic/osteogenic bipotency in vitro by fluorescence-activated cell sorting from human fetal muscle. Stem Cell Rep. 2, 92-106. doi: 10.1016/j.stemcr.2013.12.006

Cerletti, M., Molloy, M. J., Tomczak, K. K., Yoon, S., Ramoni, M. F., Kho, A. T., et al. (2006). Melanoma cell adhesion molecule is a novel marker for human fetal myogenic cells and affects myoblast fusion. J. Cell Sci. 119, 3117-3127. doi: $10.1242 /$ jcs. 03056

Charville, G. W., Cheung, T. H., Yoo, B., Santos, P. J., Lee, G. K., Shrager, J. B., et al. (2015). Ex vivo expansion and in vivo self-renewal of human muscle stem cells. Stem Cell Rep. 5, 621-632. doi: 10.1016/j.stemcr.2015.08.004

Choi, I. Y., Lim, H., Estrellas, K., Mula, J., Cohen, T. V., Zhang, Y., et al. (2016). Concordant but varied phenotypes among Duchenne Muscular Dystrophy patient-specific myoblasts derived using a human iPSC-based model. Cell Rep. 15, 2301-2312. doi: 10.1016/j.celrep.2016.05.016

Conconi, M. T., Burra, P., Di Liddo, R., Calore, C., Turetta, M., Bellini, S., et al. (2006). CD105(+) cells from Wharton's jelly show in vitro and in vivo myogenic differentiative potential. Int. J. Mol. Med. 118, 1089-1096. doi: $10.3892 /$ ijmm.18.6.1089

Conze, T., Lammers, R., Kuci, S., Scheri-Mostageer, M., Schweifer, N., Kanz, L., et al. (2003). CDCP1 is a novel marker for hematopoietic stem cells. Ann. N. Y. Acad. Sci. 996, 222-226. doi: 10.1111/j.1749-6632.2003.tb03249.x

Cossu, G., Previtali, S. C., Napolitano, S., Cicalese, M. P., Tedesco, F. S., Nicastro, F., et al. (2015). Intra-arterial transplantation of HLA-matched donor mesoangioblasts in Duchenne muscular dystrophy. EMBO Mol. Med. 7, 1513-1528. doi: 10.15252/emmm.201505636

Coussens, L., Yang-Feng, T. L., Liao, Y. C., Chen, E., Gray, A., McGrath, J., et al. (1985). Tyrosine kinase receptor with extensive homology to EGF receptor shares chromosomal location with neu oncogene. Science 230, 1132-1139. doi: $10.1126 /$ science. 2999974

Coutu, D. L., Kokkaliaris, K. D., Kunz, L., and Schroeder, T. (2017). Threedimensional map of nonhematopoietic bone and bone-marrow cells and molecules. Nat. Biotechnol. 35, 1202-1210. doi: 10.1038/nbt.4006

Crisan, M., Yap, S., Casteilla, L., Chen, C. W., Corselli, M., Park, T. S., et al. (2008). A perivascular origin for mesenchymal stem cells in multiple human organs. Cell Stem Cell 3, 301-313. doi: 10.1016/j.stem.2008.07.003

Crist, C. G., Montarras, D., and Buckingham, M. (2012). Muscle satellite cells are primed for myogenesis but maintain quiescence with sequestration of Myf5 mRNA targeted by microRNA-31 in mRNP granules. Cell Stem Cell 11, 118-126. doi: 10.1016/j.stem.2012.03.011

Darabi, R., Arpke, R. W., Irion, S., Dimos, J. T., Grskovic, M., Kyba, M., et al. (2012). Human ES- and iPS-derived myogenic progenitors restore dystrophin and improve contractility upon transplantation in dystrophic mice. Cell Stem Cell 10, 610-619. doi: 10.1016/j.stem.2012.02.015

De Angelis, L., Berghella, L., Coletta, M., Lattanzi, L., Zanchi, M., Gabriella, M., et al. (1999). Skeletal myogenic progenitors originating from embryonic dorsal aorta coexpress endothelial and myogenic markers and contribute to postnatal muscle growth and regeneration. J. Cell. Biol. 147, 869-878. doi: $10.1083 /$ jcb.147.4.869

De Bleecker, J. L., and Engel, A. G. (1994). Expression of cell adhesion molecules in inflammatory myopathies and Duchenne dystrophy. J. Neuropathol. Exp. Neurol. 53, 369-376. doi: 10.1097/00005072-199407000-00008

Deasy, B. M., Gharaibeh, B. M., Pollett, J. B., Jones, M. M., Lucas, M. A., Kanda, Y., et al. (2005). Long-term self-renewal of postnatal muscle-derived stem cells. Mol. Biol. Cell 16, 3323-3333. doi: 10.1091/mbc.e05-02-0169

Deasy, B. M., Jankowski, R. J., and Huard, J. (2001). Muscle-derived stem cells: characterization and potential for cell-mediated therapy. Blood Cells Mol. Dis. 27, 924-933. doi: 10.1006/bcmd.2001.0463

Dellavalle, A., Sampaolesi, M., Tonlorenzi, R., Tagliafico, E., Sacchetti, B., Perani, L., et al. (2007). Pericytes of human skeletal muscle are myogenic precursors distinct from satellite cells. Nat. Cell Biol. 9, 255-267. doi: 10.1038/ncb1542

Deschenes, M. R. (2004). Effects of aging on muscle fibre type and size. Sports Med. 34, 809-824. doi: 10.2165/00007256-200434120-00002

Dietrich, S., Abou-Rebyeh, F., Brohmann, H., Bladt, F., Sonnenberg-Riethmacher, E., Yamaai, T., et al. (1999). The role of SF/HGF and c-Met in the development of skeletal muscle. Development 126, 1621-1629.

Elghetany, M. T., and Patel, J. (2002). Assessment of CD24 expression on bone marrow neutrophilic granulocytes: CD24 is a marker for the myelocytic stage of development. Am. J. Hematol. 71, 348-349. doi: 10.1002/ajh.10176

Emerling, B. M., Benes, C. H., Poulogiannis, G., Bell, E. L., Courtney, K., Liu, H., et al. (2013). Identification of CDCP1 as a hypoxia-inducible factor 2alpha (HIF-2alpha) target gene that is associated with survival in clear cell renal cell carcinoma patients. Proc. Natl. Acad. Sci. U.S.A. 110, 3483-3488. doi: $10.1073 /$ pnas. 1222435110 
Fang, X., Zheng, P., Tang, J., and Liu, Y. (2017). CD24: from A to Z. Cell. Mol. Immunol. 7, 100-103. doi: 10.1038/cmi.2009.119

Figarella-Branger, D., Moreau, H., Pellissier, J. F., Bianco, N., and Rougon, G. (1993). CD24, a signal-transducing molecule expressed on human B lymphocytes, is a marker for human regenerating muscle. Acta Neuropathol. 86, 275-284. doi: 10.1007/BF00304142

Fina, L., Molgaard, H. V., Robertson, D., Bradley, N. J., Monaghan, P., Delia, D., et al. (1990). Expression of the CD34 gene in vascular endothelial cells. Blood 75, 2417-2426. doi: 10.1182/blood.V75.12.2417.2417

Fonsatti, E., Nicolay, H. J., Altomonte, M., Covre, A., and Maio, M. (2010). Targeting cancer vasculature via endoglin/CD105: a novel antibody-based diagnostic and therapeutic strategy in solid tumours. Cardiovasc. Res. 86, 12-19. doi: $10.1093 / \mathrm{cvr} / \mathrm{cvp} 332$

Franzin, C., Piccoli, M., Urbani, L., Biz, C., Gamba, P., De Coppi, P., et al. (2016). Isolation and expansion of muscle precursor cells from human skeletal muscle biopsies. Methods Mol. Biol. 1516, 195-204. doi: 10.1007/7651_2016_321

Fukasawa, K., Fujii, H., Saitoh, Y., Koizumi, K., Aozuka, Y., Sekine, K., et al. (2006). Aminopeptidase N (APN/CD13) is selectively expressed in vascular endothelial cells and plays multiple roles in angiogenesis. Cancer Lett. 243, 135-143. doi: 10.1016/j.canlet.2005.11.051

Gao, Z., Dong, K., and Zhang, H. (2014). The roles of CD73 in cancer. Biomed Res. Int. 2014:460654. doi: 10.1155/2014/460654

Garcia, S. M., Tamaki, S., Lee, S., Wong, A., Jose, A., Dreux, J., et al. (2018). Highyield purification, preservation, and serial transplantation of human satellite cells. Stem Cell Rep. 10, 1160-1174. doi: 10.1016/j.stemcr.2018.01.022

Gilliam, D. T., Menon, V., Bretz, N. P., and Pruszak, J. (2017). The CD24 surface antigen in neural development and disease. Neurobiology 99, 133-144. doi: 10.1016/j.nbd.2016.12.011

Goebels, N., Michaelis, D., Wekerle, H., and Hohlfeld, R. (1992). Human myoblasts as antigen-presenting cells. The Journal of Immunology 149, 661-667.

Goodell, M. A., Brose, K., Paradis, G., Conner, A. S., and Mulligan, R. C. (1996). Isolation and functional properties of murine hematopoietic stem cells that are replicating in vivo. J. Exp. Med. 183, 1797-1806. doi: 10.1084/jem.183.4.1797

Goudenege, S., Lebel, C., Huot, N. B., Dufour, C., Fujii, I., Gekas, J., et al. (2012). Myoblasts derived from normal hESCs and dystrophic hiPSCs efficiently fuse with existing muscle fibers following transplantation. Mol. Ther. 20, 2153-2167. doi: 10.1038/mt.2012.188

Gussoni, E., Soneoka, Y., Strickland, C. D., Buzney, E. A., Khan, M. K., Flint, A. F., et al. (1999). Dystrophin expression in the mdx mouse restored by stem cell transplantation. Nature 401, 390-394. doi: 10.1038/43919

Harel, I., Nathan, E., Tirosh-Finkel, L., Zigdon, H., Guimarães-Camboa, N., Evans, S. M., et al. (2009). Distinct origins and genetic programs of head muscle satellite cells. Dev. Cell 16, 822-832. doi: 10.1016/j.devcel.2009.05.007

Hashimoto, H., Tamaki, T., Hirata, M., Uchiyama, Y., Sato, M., and Mochida, J. (2016). Reconstitution of the complete rupture in musculotendinous junction using skeletal muscle-derived multipotent stem cell sheet-pellets as a "biobond". PeerJ 4:e2231. doi: 10.7717/peerj.2231

Hicks, M. R., Hiserodt, J., Paras, K., Fujiwara, W., Eskin, A., Jan, M., et al. (2017). ERBB3 and NGFR mark a distinct skeletal muscle progenitor cell in human development and hPSCs. Nat. Cell Biol. 20, 46-57. doi: 10.1038/s41556-017-0010-2

Hollemann, D., Budka, H., Löscher, W. N., Yanagida, G., Fischer, M. B., and Wanschitz, J. V. (2008). Endothelial and myogenic differentiation of hematopoietic progenitor cells in inflammatory myopathies. J. Neuropathol. Exp. Neurol. 67, 711-719. doi: 10.1097/NEN.0b013e31817d8064

Hosoyama, T., McGivern, J. V., Van Dyke, J. M., Ebert, A. D., and Suzuki, M. (2014). Derivation of myogenic progenitors directly from human pluripotent stem cells using a sphere-based culture. Stem Cells Transl. Med. 3, 564-574. doi: $10.5966 / \mathrm{sctm} .2013-0143$

Huss, R. (2000). Isolation of primary and immortalized CD34-hematopoietic and mesenchymal stem cells from various sources. Stem Cells 18, 1-9. doi: 10.1634/stemcells.18-1-1

Hwang, Y., Suk, S., Shih, Y. V., Seo, T., Du, B., Xie, Y., et al. (2014). WNT3A promotes myogenesis of human embryonic stem cells and enhances in vivo engraftment. Sci. Rep. 4:5916. doi: 10.1038/srep05916

Jevsek, M., Jaworski, A., Polo-Parada, L., Kim, N., Fan, J., Landmesser, L. T., et al. (2006). CD24 is expressed by myofiber synaptic nuclei and regulates synaptic transmission. Proc. Natl. Acad. Sci. U.S.A. 103, 6374-6379. doi: 10.1073/pnas.0601468103

Jiwlawat, N., Lynch, E., Jeffrey, J., Van Dyke, J. M., and Suzuki, M. (2018), Current progress and challenges for skeletal muscle differentiation from human pluripotent stem cells using transgene-free approaches. Stem Cells Int. 2018:6241681. doi: 10.1155/2018/6241681

Jiwlawat, S., Lynch, E., Glaser, J., Smit-Oistad, I., Jeffrey, J., Van Dyke, J. M., et al. (2017). Differentiation and sarcomere formation in skeletal myocytes directly prepared from human induced pluripotent stem cells using a sphere-based culture. Differentiation 96, 70-81. doi: 10.1016/j.diff.2017.07.004

Kaplan, R., Morse, B., Huebner, K., Croce, C., Howk, R., Ravera, M., et al. (1990). Cloning of three human tyrosine phosphatases reveals a multigene family of receptor-linked protein-tyrosine-phosphatases expressed in brain. Proc. Natl. Acad. Sci. U.S.A. 87, 7000-7004. doi: 10.1073/pnas.87.18.7000

Kared, H., Martelli, S., Ng, T. P., Pender, S. L., and Larbi, A. (2016). CD57 in human natural killer cells and T-lymphocytes. Cancer Immunol. Immunother. 65, 441-452. doi: 10.1007/s00262-016-1803-Z

Kehlen, A., Lendeckel, U., Dralle, H., Langner, J., and Hoang-Vu, C. (2003). Biological significance of aminopeptidase N/CD13 in thyroid carcinomas Cancer Res. 63, 8500-8506. Available online at: https://cancerres.aacrjournals. org/content/63/23/8500

Kim, J., Magli, A., Chan, S. S. K., Oliveira, V. K. P., Wu, J., Darabi, R., et al. (2017). Expansion and purification are critical for the therapeutic application of pluripotent stem cell-derived myogenic progenitors. Stem Cell Rep. 9, 12-22. doi: 10.1016/j.stemcr.2017.04.022

Koponen, J. K., Kekarainen, T., Heinonen, S. E., Laitinen, A., Nystedt, J., Laine, J., et al. (2007). Umbilical cord blood-derived progenitor cells enhance muscle regeneration in mouse hindlimb ischemia model. Mol. Ther. 15, 2172-2177. doi: 10.1038/sj.mt.6300302

Kos, L., Aronzon, A., Takayama, H., Maina, F., Ponzetto, C., Merlino, G., et al. (1999). Hepatocyte growth factor/scatter factor-MET signaling in neural crest-derived melanocyte development. Pigment Cell Res. 12, 13-21. doi: 10.1111/j.1600-0749.1999.tb00503.x

Kuang, S., Kuroda, K., Le Grand, F., and Rudnicki, M. A. (2007). Asymmetric selfrenewal and commitment of satellite stem cells in muscle. Cell 129, 999-1010. doi: 10.1016/j.cell.2007.03.044

Lapan, A. D., Rozkalne, A., and Gussoni, E. (2012). Human fetal skeletal muscle contains a myogenic side population that expresses the melanoma cell-adhesion molecule. Hum. Mol. Genet. 21, 3668-3680. doi: 10.1093/hmg/dds196

Lavasani, M., Thompson, S. D., Pollett, J. B., Usas, A., Lu, A., Stolz, D. B., et al. (2014). Human muscle-derived stem/progenitor cells promote functional murine peripheral nerve regeneration. J. Clin. Investig. 124, 1745-1756. doi: 10.1172/JCI44071

Le Grand, F., Jones, A. E., Seale, V., Scime, A., and Rudnicki, M. A. (2009). Wnt7a activates the planar cell polarity pathway to drive the symmetric expansion of satellite stem cells. Cell Stem Cell 4, 535-547. doi: 10.1016/j.stem.2009. 03.013

Lecourt, S., Marolleaude, J. P., Fromigue, O., Vauchez, K., Andriamanalijaona, R., Ternaux, B., et al. (2010). Characterization of distinct mesenchymal-like cell populations from human skeletal muscle in situ and in vitro. Exp. Cell Res. 316, 2513-2526. doi: 10.1016/j.yexcr.2010.04.020

Leroy, M. C., Perroud, J., Darbellay, B., Bernheim, L., and Konig, S. (2013). Epidermal growth factor receptor down-regulation triggers human myoblast differentiation. PLoS ONE 8:e71770. doi: 10.1371/journal.pone.0071770

Lertkiatmongkol, P., Liao, D., Mei, H., Hu, Y., and Newman, P. J. (2016). Endothelial functions of PECAM-1 (CD31). Curr. Opin. Hematol. 23, 253-259. doi: $10.1097 / \mathrm{MOH} .0000000000000239$

Lin, C. S., Ning, H., Lin, G., and Lue, T. F. (2012). Is CD34 truly a negative marker for mesenchymal stromal cells? Cytotherapy 14, 1159-1163. doi: $10.3109 / 14653249.2012 .729817$

Lindström, M., and Thornell, L. E. (2009). New multiple labelling method for improved satellite cell identification in human muscle: application to a cohort of power-lifters and sedentary men. Histochem. Cell Biol. 132, 141-157. doi: 10.1007/s00418-009-0606-0

Liu, L., Cheung, T. H., Charville, G. W., and Rando, T. A. (2015). Isolation of skeletal muscle stem cells by fluorescence-activated cell sorting. Nat. Protoc. 10, 1612-1624. doi: 10.1038/nprot.2015.110 
Long, E. O. (2011). Intercellular Adhesion Molecule 1 (ICAM-1): Getting a grip on leukocyte adhesion. J. Immunol. 186, 5021-5023. doi: 10.4049/jimmunol.1100646

Lorant, J., Saury, C., Schleder, C., Robriquet, F., Lieubeau, B., Negroni, E., et al. (2018). Skeletal muscle regenerative potential of human MuStem cells following transplantation into injured mice muscle. Mol. Ther. 26, 618-633. doi: 10.1016/j.ymthe.2017.10.013

Lui, P. P. (2015). Markers for the identification of tendon-derived stem cells in vitro and tendon stem cells in situ - update and future development. Stem Cell Res. Ther. 6:106. doi: 10.1186/s13287-015-0097-y

Maesner, C. C., Almada, A. E., and Wagers, A. J. (2016). Established cell surface markers efficiently isolate highly overlapping populations of skeletal muscle satellite cells by fluorescence-activated cell sorting. Skelet. Muscle 6:35. doi: 10.1186/s13395-016-0106-6

Maffioletti, S. M., Gerli, M. F., Ragazzi, M., Dastidar, S., Benedetti, S., Loperfido, M., et al. (2015). Efficient derivation and inducible differentiation of expandable skeletal myogenic cells from human ES and patient-specific iPS cells. Nat. Protoc. 10, 941-958. doi: 10.1038/nprot.2015.057

Magli, A., Incitti, T., Kiley, J., Swanson, S. A., Darabi, R., Rinaldi, F., et al. (2017). PAX7 Targets, CD54, Integrin $\alpha 9 \beta 1$ and SDC2, allow isolation of human ES/iPS cell-derived myogenic progenitors. Cell Rep. 19, 2867-2877. doi: 10.1016/j.celrep.2017.06.005

Maguer-Satta, V., Besançon, R., and Bachelard-Cascales, E. (2011). Concise review: neutral endopeptidase (CD10): a multifaceted environment actor in stem cells, physiological mechanisms, and cancer. Stem Cells 29, 389-396. doi: 10.1002/stem.592

Marg, A., Escobar, H., Gloy, S., Kufeld, M., Zacher, J., Spuler, A., et al. (2014). Human satellite cells have regenerative capacity and are genetically manipulable. J. Clin. Investig. 124, 4257-4265. doi: 10.1172/JCI63992

Marino, M., Scuderi, F., Mannella, F., and Bartoccioni, E. (2003). TGFbeta 1 and IL-10 modulate IL-1 beta-induced membrane and soluble ICAM-1 in human myoblasts. J. Neuroimmunol. 134, 151-157. doi: 10.1016/S0165-5728(02)00399-5

Marino, M., Scuderi, F., Mazzarelli, P., Mannella, F., Provenzano, C., and Bartoccioni, E. (2001). Constitutive and cytokine-induced expression of MHC and intercellular adhesion molecule-1 (ICAM-1) on human myoblasts. J. Neuroimmunol. 116, 94-101. doi: 10.1016/S0165-5728(01)00287-9

Mary, P., Servais, L., and Vialle, R. (2018). Neuromuscular diseases: Diagnosis and management. Orthop. Traumatol. Surg. Res. 104, S89-S95. doi: 10.1016/j.otsr.2017.04.019

Marzetti, E., Calvani, R., Tosato, M., Cesari, M., Di Bari, M., Cherubini, A., et al. (2017). Sarcopenia: an overview. Aging Clin. Exp. Re. 29, 11-17. doi: 10.1007/s40520-016-0704-5

Mauro, A. (1961). Satellite cell of skeletal muscle fibers. J. Biophys. Biochem. Cytol. 9:493-495. doi: 10.1083/jcb.9.2.493

Meadows, E., Cho, J. H., Flynn, J. M., and Klein, W. H. (2008). Myogenin regulates a distinct genetic program in adult muscle stem cells. Dev. Biol. 322, 406-414. doi: 10.1016/j.ydbio.2008.07.024

Meng, J., Chun, S., Asfahani, R., Lochmüller, H., Muntoni, F., and Morgan, J. (2014). Human skeletal muscle-derived CD133(+) cells form functional satellite cells after intramuscular transplantation in immunodeficient host mice. Mol. Ther. J. Am. Soc. Gene Ther. 22, 1008-1017. doi: 10.1038/mt.2014.26

Michaelis, D., Goebels, N., and Hohlfeld, R. (1993). Constitutive and cytokineinduced expression of human leukocyte antigens and cell adhesion molecules by human myotubes. Am. J. Pathol. 143, 1142-1149.

Morgan, J. E., and Partridge, T. A. (2003). Muscle satellite cells. Int. J. Biochem. Cell Biol. 35, 1151-1156. doi: 10.1016/S1357-2725(03) 00042-6

Morosetti, R., Mirabella, M., Gliubizzi, C., Broccolini, A., De Angelis, L., Tagliafico, E., et al. (2006). MyoD expression restores defective myogenic differentiation of human mesoangioblasts from inclusion-body myositis muscle. Proc. Natl. Acad. Sci. U.S.A. 103, 16995-17000. doi: 10.1073/pnas.06033 86103

Morrison, B. M. (2016). Neuromuscular diseases. Semin. Neurobiol. 36, 409-418. doi: $10.1055 / \mathrm{s}-0036-1586263$

Narici, M. V., and Maffulli, N. (2010). Sarcopenia: characteristics, mechanisms and functional significance. Br. Med. Bull. 95, 139-159. doi: 10.1093/bmb/ ldq008
Negroni, E., Riederer, I., Chaouch, S., Melicchi, M., Razini, P., Di Santo, J., et al. (2009). In vivo myogenic potential of human CD133+ muscle-derived stem cells: a quantitative study. Mol. Ther. J. Am. Soc. Gene Ther. 17, 1771-1778. doi: $10.1038 / \mathrm{mt} .2009 .167$

Nunes, V. A., Cavacana, N., Canovas, M., Strauss, B. E., and Zatz, M. (2007). Stem cells from umbilical cord blood differentiate into myotubes and express dystrophin in vitro only after exposure to in vivo muscle environment. Biol. Cell 99, 185-196. doi: 10.1042/BC20060075

Ogawa, S., Yakabe, M., and Akishita, M. (2016). Age-related sarcopenia and its pathophysiological bases. Inflamm. Regener. 36:17. doi: 10.1186/s41232-016-0022-5

Okada, M., Payne, T. R., Drowley, L., Jankowski, R. J., Momoi, N., Beckman, S., et al. (2012). Human skeletal muscle cells with a slow adhesion rate after isolation and an enhanced stress resistance improve function of ischemic hearts. Mol. Ther. 20:138145. doi: 10.1038/mt.2011.229

Pallafacchina, G., Blaauw, B., and Schiaffino, S. (2013). Role of satellite cells in muscle growth and maintenance of muscle mass. Nutr. Metab. Cardiovasc. Dis. 23(Suppl. 1), S12-S18. doi: 10.1016/j.numecd.2012.02.002

Park, T. S., Gavina, M., Chen, C. W., Sun, B., Teng, P., Huard, J., et al. (2011). Placental perivascular cells for human muscle regeneration. Stem Cells Dev. 20, 451-463. doi: 10.1089/scd.2010.0354

Péault, B., Rudnicki, M., Torrente, Y., Cossu, G., Tremblay, J. P., Partridge, T., et al. (2007). Stem and progenitor cells in skeletal muscle development, maintenance, and therapy. Mol. Ther. 15, 867-877. doi: 10.1038/mt.sj.6300145

Pisani, D. F., Clement, N., Loubat, A., Plaisant, M., Sacconi, S., Kurzenne, J., et al. (2010a). Hierarchization of myogenic and adipogenic progenitors within human skeletal muscle. Stem Cells 28, 2182-2194. doi: 10.1002/stem.537

Pisani, D. F., Dechesne, C. A., Sacconi, S., Delplace, S., Belmonte, N., Cochet, O., et al. (2010b). Isolation of a highly myogenic CD34-negative subset of human skeletal muscle cells free of adipogenic potential. Stem Cells J. 28, 753-764. doi: $10.1002 /$ stem.317

Polisetty, N., Fatima, A., Madhira, S. L., Sangwan, V. S., and Vemuganti, G. K. (2008). Mesenchymal cells from limbal stroma of human eye. Mol. Vis. 14, 431-442. Available online at: https://www.ncbi.nlm.nih.gov/pmc/articles/ PMC2268845/

Poncet, C., Frances, V., Gristina, R., Scheiner, C., Pellissier, J. F., and FigarellaBranger, D. (1996). CD24, a glycosylphosphatidylinositol-anchored molecule is transiently expressed during the development of human central nervous system and is a marker of human neural cell lineage tumors. Acta Neuropathol. 91, 400-408. doi: 10.1007/s004010050442

Poole, C. A., Brookes, N. H., and Clover, G. M. (1993). Keratocyte networks visualised in the living cornea using vital dyes. J. Cell Sci. 106, 685-691.

Popescu, L. M., Ciontea, S. M., and Cretoiu, D. (2007). Interstitial Cajal-like cells in human uterus and fallopian tube. Ann. N. Y. Acad. Sci. 1101, 139-165. doi: 10.1196/annals. 1389.022

Proksch, S., Bel, A., Puymirat, E., Pidial, L., Bellamy, V., Peyrard, S., et al. (2009). Does the human skeletal muscle harbor the murine equivalents of cardiac precursor cells? Mol. Ther. 17, 733-741. doi: 10.1038/mt.2009.6

Qu-Petersen, Z., Deasy, B., Jankowski, R., Ikezawa, M., Cummins, J., Pruchnic, R., et al. (2002). Identification of a novel population of muscle stem cells in mice: potential for muscle regeneration. J. Cell Biol. 157, 851-864. doi: $10.1083 /$ jcb. 200108150

Rahman, M. M., Ghosh, M., Subramani, J., Fong, G. H., Carlson, M. E., and Shapiro, L. H. (2014). CD13 regulates anchorage and differentiation of the skeletal muscle satellite stem cell population in ischemic injury. Stem Cells 32, 1564-1577. doi: 10.1002/stem.1610

Ramos, L. T., Sánchez-Abarca, L. I., Muntión, S., Preciado, S., Puig, N., LopezRuano, G., et al. (2016). MSC surface markers (CD44, CD73, and CD90) can identify human MSC-derived extracellular vesicles by conventional flow cytometry. Cell Commun. Signal. 14:2. doi: 10.1186/s12964-015-0124-8

Rao, L., Qian, Y., Khodabukus, A., Ribar, T., and Bursac, N. (2018). Engineering human pluripotent stem cells into a functional skeletal muscle tissue. Nat. Commun. 9:126. doi: 10.1038/s41467-017-02636-4

Rasmussen, H., Hansen, A., Smedts, F., Rumessen, J. J., and Horn, T. (2007). CD34-positive interstitial cells of the human detrusor. APMIS 115, 1260-1266. doi: 10.1111/j.1600-0643.2007.00759.x

Razorenova, O. V., Finger, E. C., Colavitti, R., Chernikova, S. B., Boiko, A. D., Chan, C. K., et al. (2011). VHL loss in renal cell carcinoma leads to up-regulation 
of CUB domain-containing protein 1 to stimulate PKCdelta-driven migration. Proc. Natl. Acad. Sci. U.S.A. 108, 1931-1936. doi: 10.1073/pnas.1011777108

Ryder, S., Leadley, R. M., Armstrong, N., Westwood, M., de Kock, S., Butt, T., et al. (2017). The burden, epidemiology, costs and treatment for Duchenne muscular dystrophy: an evidence review. Orphanet J. Rare Dis. 12:79. doi: $10.1186 / \mathrm{s} 13023-017-0631-3$

Sakai-Takemura, F., Narita, A., Masuda, S., Wakamatsu, T., Watanabe, N., Nishiyama, T., et al. (2018). Premyogenic progenitors derived from human pluripotent stem cells expand in floating culture and differentiate into transplantable myogenic progenitors. Sci. Rep. 8:6555. doi: 10.1038/s41598-018-24959-y

Sambasivan, R., Gayraud-Morel, B., Dumas, G., Cimper, C., Paisant, S., Kelly, R. G., et al. (2009). Distinct regulatory cascades govern extraocular and pharyngeal arch muscle progenitor cell fates. Dev. Cell 16, 810-821. doi: 10.1016/j.devcel.2009.05.008

Sampaolesi, M., Torrente, Y., Innocenzi, A., Tonlorenzi, R., D’Antona, G., Pellegrino, M. A., et al. (2003). Cell therapy of alpha-sarcoglycan null dystrophic mice through intraarterial delivery of mesoangioblasts. Science 301, 487-492. doi: 10.1126/science. 1082254

Santilli, V., Bernetti, A., Mangone, M., and Paoloni, M. (2014). Clinical definition of sarcopenia. Clin. Cases Mineral Bone Metab. 11, 177-180. doi: $10.11138 / \mathrm{ccmbm} / 2014.11 .3 .177$

Scutt, N., Rolf, C. G., and Scutt, A. (2008). Tissue specific characteristics of cells isolated from human and rat tendons and ligaments. J. Orthop. Surg. Res. 3:32. doi: 10.1186/1749-799X-3-32

Seale, P., Sabourin, L. A., Girgis-Gabardo, A., Mansouri, A., Gruss, P., and Rudnicki, M. A. (2000). Pax7 is required for the specification of myogenic satellite cells. Cell 102, 777-786. doi: 10.1016/S0092-8674(00)00066-0

Senbanjo, L. T., and Chellaiah, M. A. (2017). CD44: A multifunctional cell surface adhesion receptor is a regulator of progression and metastasis of cancer cells. Front. Cell Develop. Biol. 5:18. doi: 10.3389/fcell.2017.00018

Sidney, L. E., Branch, M. J., Dunphy, S. E., Dua, H. S., and Hopkinson, A. (2014). Concise review: evidence for CD34 as a common marker for diverse progenitors. Stem Cells 32, 1380-1389. doi: 10.1002/stem.1661

Sinanan, A. C. M., Hunt, N. P., and Lewis, M. P. (2004). Human adult craniofacial muscle-derived cells: neural-cell adhesion-molecule (NCAM; CD56)-expressing cells appear to contain multipotential stem cells. Biotechnol. Appl. Biochem. 40, 25-34. doi: 10.1042/BA20030185

Skoglund, G., Lainé, J., Darabi, R., Fournier, E., Perlingeiro, R., and Tabti, N. (2014). Physiological and ultrastructural features of human induced pluripotent and embryonic stem cell-derived skeletal myocytes in vitro. Proc. Natl. Acad. Sci. U.S.A. 111, 8275-8280. doi: 10.1073/pnas.1322258111

Smyth, L. C. D., Rustenhoven, J., Scotter, E. L., Schweder, P., Faull, R. L. M., Park, T. I. H., et al. (2018). Markers for human brain pericytes and smooth muscle cells. J. Chem. Neuroanat. 92, 48-60. doi: 10.1016/j.jchemneu.2018.06.001

Spassov, D. S., Baehner, F. L., Wong, C. H., McDonough, S., and Moasser, M. M. (2009). The transmembrane src substrate Trask is an epithelial protein that signals during anchorage deprivation. Am. J. Pathol. 174, 1756-1765. doi: 10.2353/ajpath.2009.080890

Starkey, J. D., Yamamoto, M., Yamamoto, S., and Goldhamer, D. J. (2011). Skeletal muscle satellite cells are committed to myogenesis and do not spontaneously adopt nonmyogenic fates. J. Histochem. Cytochem. 59, 33-46. doi: $10.1369 /$ jhc.2010.956995

Stolk, M., Klatte-Schulz, F., Schmock, A., Minkwitz, S., Wildemann, B., and Seifert, M. (2017). New insights into tenocyte-immune cell interplay in an in vitro model of inflammation. Sci. Rep. 7:9801. doi: 10.1038/s41598-017-09875-x

Takahashi, K., Tanabe, K., Ohnuki, M., Narita, M., Ichisaka, T., Tomoda, K., et al. (2007). Induction of pluripotent stem cells from adult human fibroblasts by defined factors. Cell 131, 861-872. doi: 10.1016/j.cell.2007.11.019

Tamajusuku, A. S., Carrillo-Sepúlveda, M. A., Braganhol, E., Wink, E. R., Sarkis, J. J.,Barreto-Chaves, M. L., et al. (2006). Activity and expression of ecto-5' nucleotidase/CD73 are increased by thyroid hormones in vascular smooth muscle cells. Mol. Cell. Biochem. 289, 65-72. doi: 10.1007/s11010-006-9148-0

Tan, Y., Zhao, M., Xiang, B., Chang, C., and Lu, Q. (2016). CD24: from a hematopoietic differentiation antigen to a genetic risk factor for multiple autoimmune diseases. Clin. Rev. Allergy Immunol. 50, 70-83. doi: $10.1007 / \mathrm{s} 12016-015-8470-2$
Tanaka, A., Woltjen, K., Miyake, K., Hotta, A., Ikeya, M., Yamamoto, T., et al. (2013). Efficient and reproducible myogenic differentiation from human iPS cells: prospects for modeling Miyoshi Myopathy in vitro. PLoS ONE 8:e61540. doi: 10.1371/annotation/63972dc9-3a31-43d0-ad52-bc46fd948c03

Tapscott, S. J., Davis, R. L., Thayer, M. J., Cheng, P. F., Weintraub, H., and Lassar, A. B. (1988). MyoD1: a nuclear phosphoprotein requiring a Myc homology region to convert fibroblasts to myoblasts. Science 242, 405-411. doi: $10.1126 /$ science. 3175662

Tchao, J., Kim, J. J., Lin, B., Salama, G., Lo, C. W., Yang, L., et al. (2013). Engineered human muscle tissue from skeletal muscle derived stem cells and induced pluripotent stem cell derived cardiac cells. Int. J. Tissue Eng. 2013:198762. doi: 10.1155/2013/198762

Tedesco, F. S., Gerli, M. F. M., Perani, L., Benedetti, S., Ungaro, F., Cassano, M., et al. (2012). Transplantation of genetically corrected human iPSC-derived progenitors in mice with limb-girdle muscular dystrophy. Sci. Transl. Med. 4:140ra89. doi: 10.1126/scitranslmed.3003541

Teo, A. K., Ali, Y., Wong, K. Y., Chipperfield, H., Sadasivam, A., Poobalan, Y., et al. (2012). Activin and BMP4 synergistically promote formation of definitive endoderm in human embryonic stem cells. Stem Cells 30, 631-642. doi: $10.1002 /$ stem. 1022

Thapa, R., and Wilson, G. D. (2016). The importance of CD44 as a stem cell biomarker and therapeutic target in cancer. Stem Cells Int. 2016:2087204. doi: $10.1155 / 2016 / 2087204$

Thomson, J. A. (1998). Embryonic stem cell lines derived from human blastocysts. Science 282, 1145-1147. doi: 10.1126/science.282.5391.1145

Tompkins, B. A., DiFede, D. L., Khan, A., Landin, A. M., Schulman, I. H., Pujol, M. V., et al. (2017). Allogeneic mesenchymal stem cells ameliorate aging frailty: a phase II randomized, double-blind, placebo-controlled clinical trial. J. Gerontol. Ser. A Biol. Sci. Med. Sci. 72, 1513-1522. doi: 10.1093/gerona/glx137

Tonlorenzi, R., Dellavalle, A., Schnapp, E., Cossu, G., and Sampaolesi, M. (2007). Isolation and characterization of mesoangioblasts from mouse, dog, and human tissues. Curr. Protocols Stem Cell Biol. Chapter 2:Unit 2B.1. doi: $10.1002 / 9780470151808 . s c 02 b 01 s 3$

Tonoli, H., and Barrett, J. C. (2005). CD82 metastasis suppressor gene: a potential target for new therapeutics? Trends Mol. Med. 11, 563-570. doi: 10.1016/j.molmed.2005.10.002

Uekita, T., and Sakai, R. (2011). Roles of CUB domain-containing protein 1 signaling in cancer invasion and metastasis. Cancer Sci. 102, 1943-1948. doi: 10.1111/j.1349-7006.2011.02052.x

Uezumi, A., Nakatani, M., Ikemoto-Uezumi, M., Yamamoto, N., Morita, M., Yamaguchi, A., et al. (2016). Cell-surface protein profiling identifies distinctive markers of progenitor cells in human skeletal muscle. Stem Cell Rep. 7, 263-278. doi: 10.1016/j.stemcr.2016.07.004

Usas, A., Maciulaitis, J., Maciulaitis, R., Jakuboniene, N., Milasius, A., and Huard, J. (2011). Skeletal muscle-derived stem cells: implications for cellmediated therapies. Medicina 47, 469-479. doi: 10.3390/medicina47090068

Vailhe, B., Vittet, D., and Feige, J. J. (2001). In vitro models of vasculogenesis and angiogenesis. Lab. Invest. 81, 439-452. doi: 10.1038/labinvest.3780252

Vasyutina, E., Stebler, J., Brand-Saberi, B., Schulz, S., Raz, E., and Birchmeier, C. (2005). CXCR4 and Gab1 cooperate to control the development of migrating muscle progenitor cells. Genes Dev. 19, 2187-2198. doi: 10.1101/gad.346205

Vella, J. B., Thompson, S. D., Bucsek, M. J., Song, M., and Huard, J. (2011). Murine and human myogenic cells identified by elevated aldehyde dehydrogenase activity: implications for muscle regeneration and repair. PLoS ONE 6:e29226. doi: 10.1371/journal.pone.0029226

Villa, C. H., Shore, T., Van Besein, K., and Cushing, M. (2012). Addition of plerixafor to mobilization regimens in autologus peripheral blood stem cell transplants does not affect the correlation of preharvest hematopoietic precursor cell enumeration with first harvest CD34+ stem cell yield. Biol. Blood Marrow Transplant. 18, 1867-1875. doi: 10.1016/j.bbmt.2012.07.002

Walenkamp, A. M. E., Lapa, C., Herrmann, K., and Wester, H. J. (2017). CXCR4 ligands: The next big hit? J. Nuclear Med. 58, 77S-82S. doi: 10.2967/jnumed.116.186874

Wang, Z., and Yan, X. (2013). CD146, a multi-functional molecule beyond adhesion. Cancer Lett. 330, 150-162. doi: 10.1016/j.canlet.2012.11.049

Wetzel, A., Chavakis, T., Preissner, K. T., Sticherling, M., Haustein, U., Anderegg, U., et al. (2004). Human Thy-1 (CD90) on activated endothelial cells is a 
counterreceptor for the leukocyte integrin Mac-1 (CD11b/CD18). J. Immunol. 172, 3850-3859. doi: 10.4049/jimmunol.172.6.3850

Wilschut, K. J., Ling, V. B., and Bernstein, H. S. (2012). Concise review: stem cell therapy for muscular dystrophies. Stem Cells Transl. Med. 1, 833-842. doi: $10.5966 / \mathrm{sctm} .2012-0071$

Woodard, G. E., Ji, Y., Christopherson, G. T., Wolcott, K. M., Hall, D. J., Jackson, W. M., et al. (2014). Characterization of discrete subpopulations of progenitor cells in traumatic human extremity wounds. PLoS ONE 9:e114318. doi: 10.1371/journal.pone.0114318

Wu, J., Matthias, N., Lo, J., Ortiz-Vitali, J. L., Shieh, A. W., Wang, S. H., et al. (2018). A myogenic double-reporter human pluripotent stem cell line allows prospective isolation of skeletal muscle progenitors. Cell Rep. 25, 1966-1981.e4. doi: 10.1016/j.celrep.2018.10.067

Xu, X., Wilschut, K. J., Kouklis, G., Tian, H., Hesse, R., Garland, C., et al. (2015). Human satellite cell transplantation and regeneration from diverse skeletal muscles. Stem Cell Rep. 5, 419-434. doi: 10.1016/j.stemcr.2015.07.016

Yang, J., Jian, R., Yu, J., Zhi, X., Liao, X., Yu, J., et al. (2015). CD73 regulates vascular smooth muscle cell functions and facilitates atherosclerotic plaque formation. IUBMB Life 67, 853-860. doi: 10.1002/iub.1448

Yang, Z. X., Han, Z., Ji, Y. R., Wang, Y. W., Liang, L., Chi, Y., et al. (2013). CD106 identifies a subpopulation of mesenchymal stem cells with unique immunomodulatory properties. PLoS ONE 8:e59354. doi: 10.1371/journal.pone.0059354

Yasuno, T., Osafune, K., Sakurai, H., Asaka, I., Tanaka, A., Yamaguchi, S., et al. (2014). Functional analysis of iPSC-derived myocytes from a patient with carnitine palmitoyltransferase II deficiency. Biochem. Biophys. Res. Commun. 448, 175-181. doi: 10.1016/j.bbrc.2014.04.084
Yu, W., Zeidel, M. L., and Hill, W. G. (2012). Cellular expression profile for interstitial cells of cajal in bladder - a cell often misidentified as myocyte or myofibroblast. PLoS ONE 7:e48897. doi: 10.1371/journal.pone.00 48897

Zadeh, M. S., Kolb, J., Geromin, D., D’Anna, R., Boulmerka, A., Marconi, A., et al. (2000). Regulation of ICAM-1/CD54 expression on human endothelial cells by hydrogen peroxide involves inducible NO synthase. J. Leukoc. Biol. 67, 327-334. doi: $10.1002 / \mathrm{jlb} \cdot 67.3 .327$

Zheng, B., Cao, B., Crisan, M., Sun, B., Li, G., Logar, A., et al. (2007). Prospective identification of myogenic endothelial cells in human skeletal muscle. Nat. Biotechnol. 25, 1025-1034. doi: 10.1038/nbt1334

Zheng, B., Chen, C. W., Li, G., Thompson, S. D., Poddar, M., Peault, B., et al. (2012). Isolation of myogenic stem cells from cultures of cryopreserved human skeletal muscle. Cell Transplant. 21, 1087-1093. doi: 10.3727/096368912X 636876

Conflict of Interest: The authors declare that the research was conducted in the absence of any commercial or financial relationships that could be construed as a potential conflict of interest.

Copyright $\odot 2019$ Tey, Robertson, Lynch and Suzuki. This is an open-access article distributed under the terms of the Creative Commons Attribution License (CC BY). The use, distribution or reproduction in other forums is permitted, provided the original author(s) and the copyright owner(s) are credited and that the original publication in this journal is cited, in accordance with accepted academic practice. No use, distribution or reproduction is permitted which does not comply with these terms. 